\begin{tabular}{l}
$\overrightarrow{\mathrm{P}_{\mathrm{H}}}$ \\
\hline
\end{tabular}

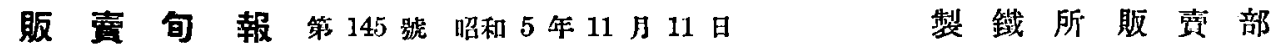
北支那の銀材市場 (其 2)

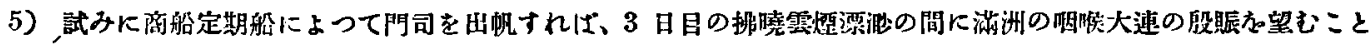

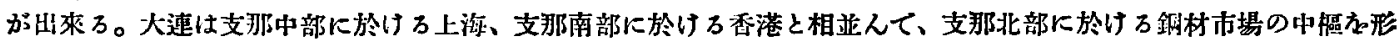

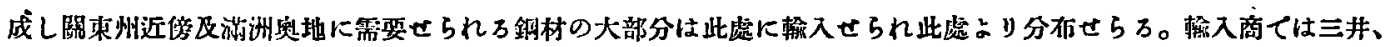

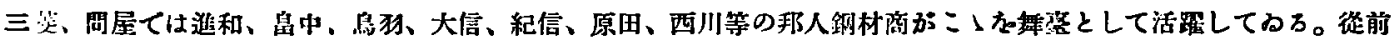

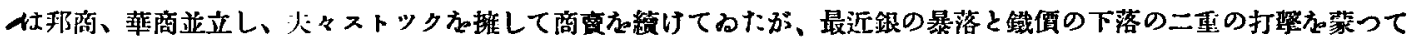

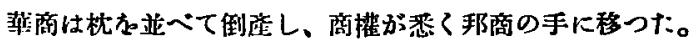

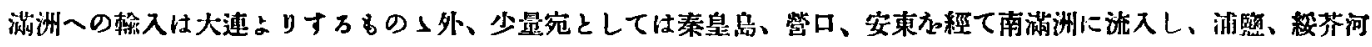

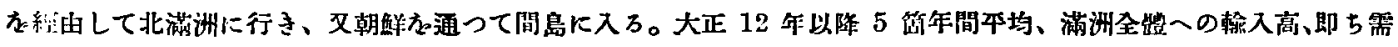

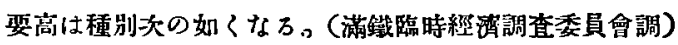

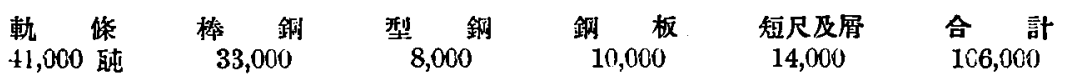

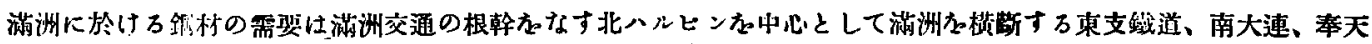

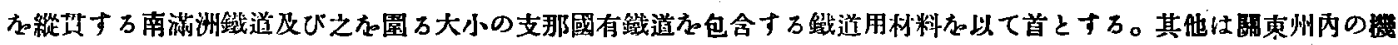

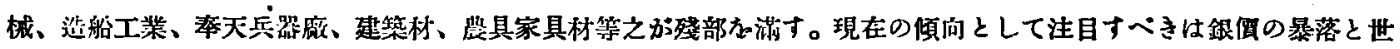

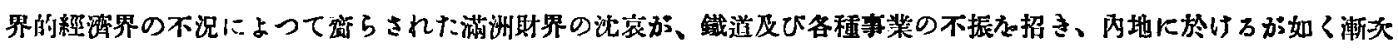

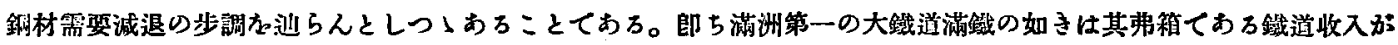

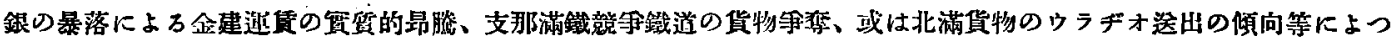

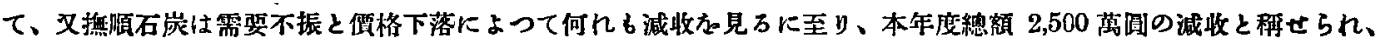

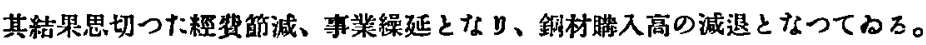

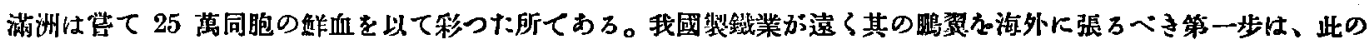

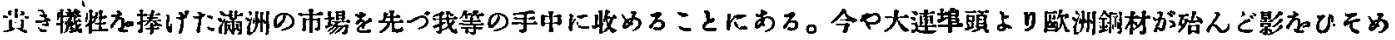

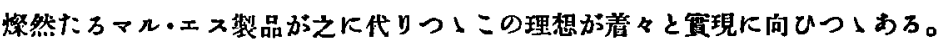

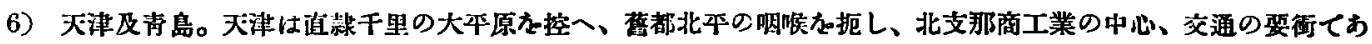

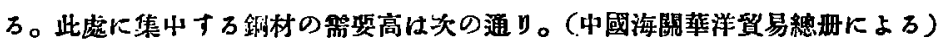

\begin{tabular}{|c|c|c|c|c|c|c|}
\hline 年次入品種 & 軌 & 棒 & 型 & 䥄 & 短尺及屑 & 合 部 \\
\hline 1926 年 & 4,000 & 10,700 & 2,700 & 6,900 & 9,900 & 34,200 \\
\hline 1927 年 & 400 & 9,300 & 1,000 & 5,200 & 11,600 & 27,500 \\
\hline 1928 年 & 600 & 7,000 & 1,100 & 6,630 & 9,360 & 24,600 \\
\hline
\end{tabular}

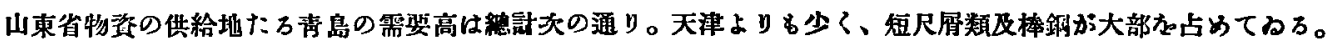
1926 年 5,800 䣩 1927 年 $4,900 \quad 1928$ 年 5,800

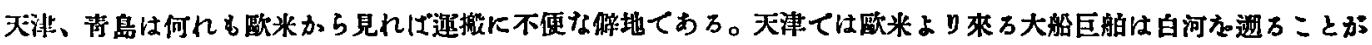

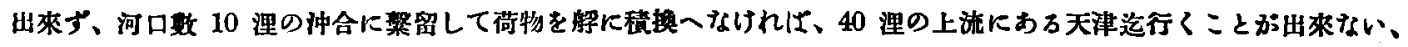

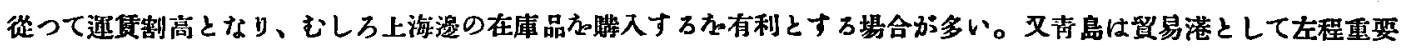

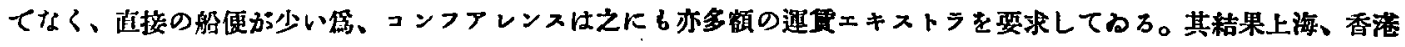

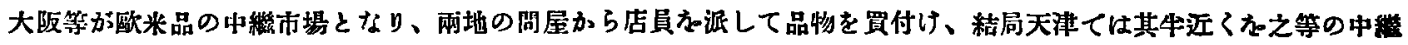

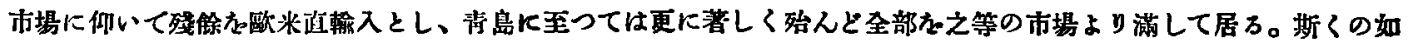

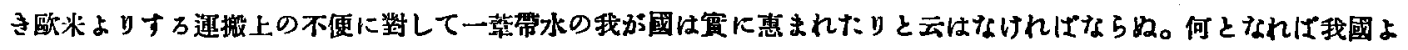

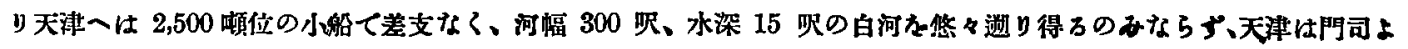




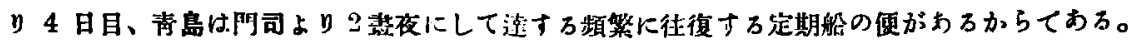

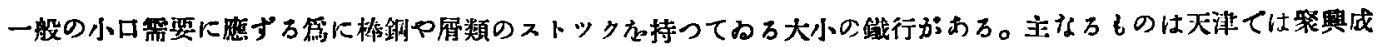

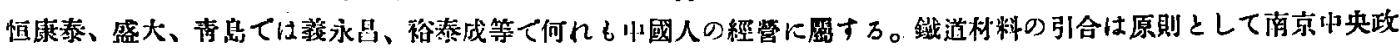

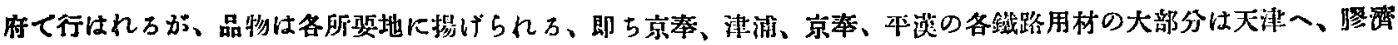
践路の分け青島に输入されてるる。

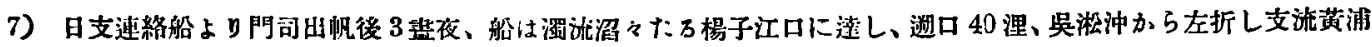

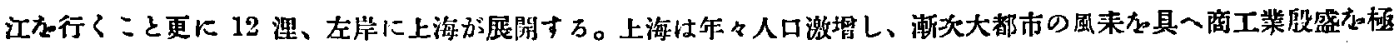
め行くが故に東洋のニニーョークと积せられ、又各國の絕好の输出向先たかが故に世界のダンヒング市場とる云はる

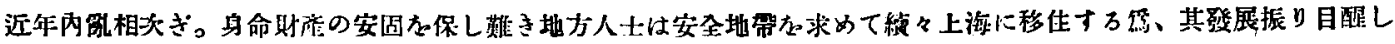

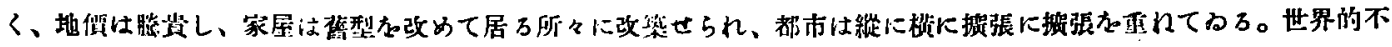

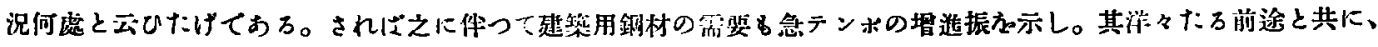

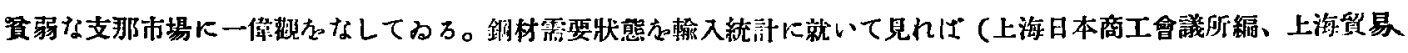
明絧表に依乃)

\begin{tabular}{|c|c|c|c|c|c|c|c|}
\hline 品種 & 棒 & 山形銅 & 工、满、丁形稍 & 轨 & 钢 & 短尺及展 & 合計 \\
\hline $19: 27$ 年 & 20,000 & $\begin{array}{l}3,000 \\
6000\end{array}$ & 2,000 & 1,000 & $\begin{array}{l}15,000 \\
23,000\end{array}$ & $\begin{array}{l}39,000) \\
91,000\end{array}$ & $\begin{array}{r}80,000 \\
150,000\end{array}$ \\
\hline 1929 年 & 年, 4000 & $\begin{array}{r}0,000 \\
10,000\end{array}$ & 4,000 & 5,000 & 24,000 & 91,000 & 181,000 \\
\hline
\end{tabular}

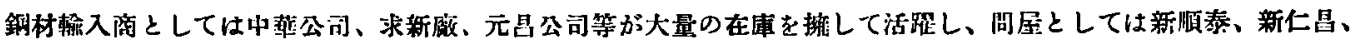
蔡仁茂、正大稂、瑞新服、怡生、可熾、源昌、裕記、合昌等がブロードウェィから蘚州路にかけて一带の金物町か作 つてふろ。同地に於いて使用される建䓩用銅材に就いて注目すべきことは。

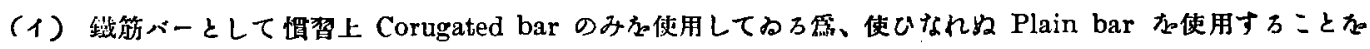
喜ぱはいこと。

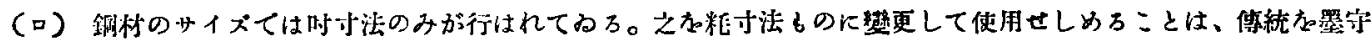

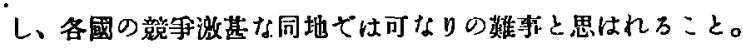

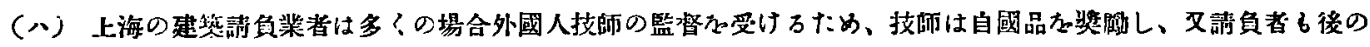

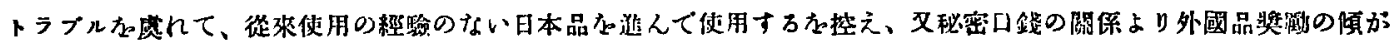
おろ と。

( ) Stock deliver の契約が多いこと等でるる。

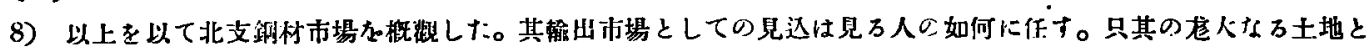

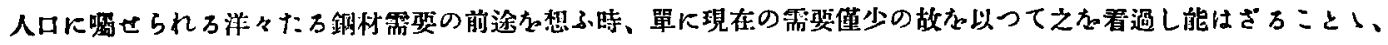
及ひ同地一の榆出上我國が最る地理的條件に保越し、支那買手し亦取引の手近に行はれることによりて得万利盆方知

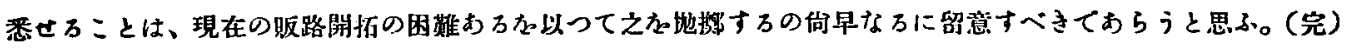

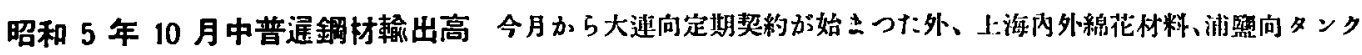

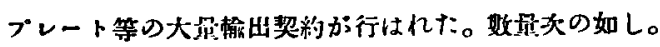

\begin{tabular}{|c|c|c|c|c|c|c|c|c|}
\hline $\begin{array}{l}\text { 向 北 别 } \\
\text { 10 累到 }\end{array}$ & $\begin{array}{c}\text { 大連及牛莊 } \\
1,234 \\
3,564\end{array}$ & $\begin{array}{l}\text { 天 津 } \\
152 \\
449\end{array}$ & $\begin{array}{l}\text { 上 海 } \\
410 \\
1,017\end{array}$ & $\begin{array}{l}\text { 请 } \\
197 \\
197\end{array}$ & $\begin{array}{c}\text { 淡 口 } \\
30 \\
103\end{array}$ & $\begin{array}{r}\text { 浦贜 } \\
512 \\
1,819\end{array}$ & $\begin{array}{c}\text { ヒリッビン } \\
\overline{62}\end{array}$ & $\begin{array}{r}\text { 合 計 } \\
2,535 \\
7,210\end{array}$ \\
\hline
\end{tabular}

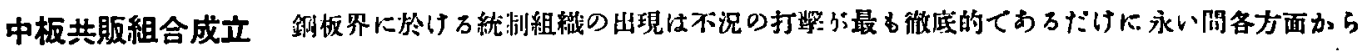

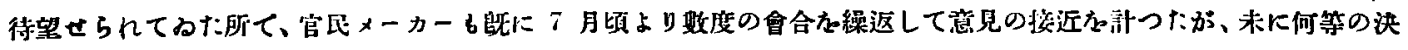

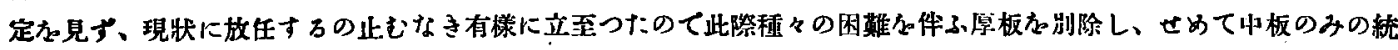

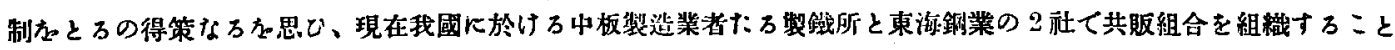

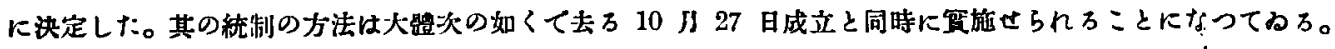

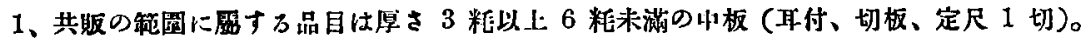

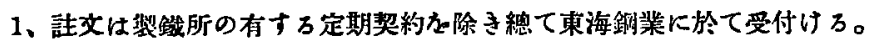

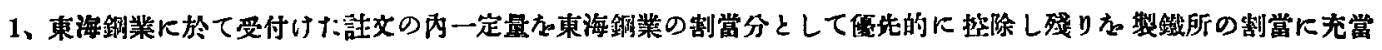
すか。 


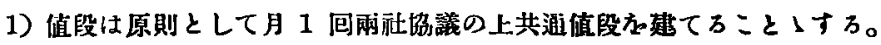

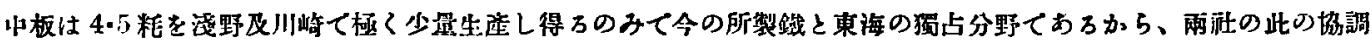

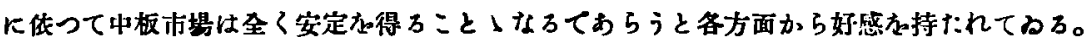

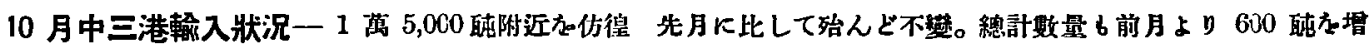

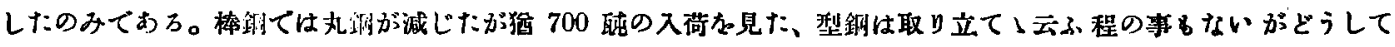

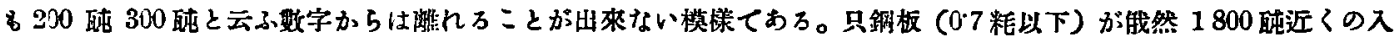
荷を見て警異の的となつて居ろ、内容は 28 番、30 番の $21 / 2 \times 678$ と云ふ長尺物が大部を占的て居万。錻力は内地

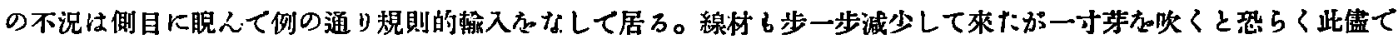
は清ますまい。

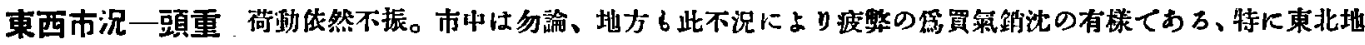

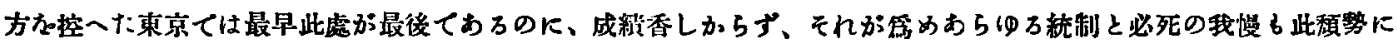

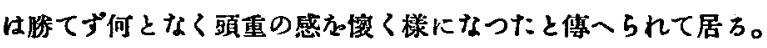

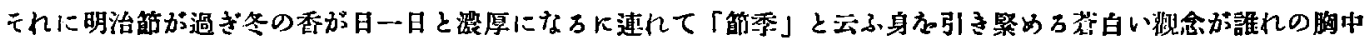

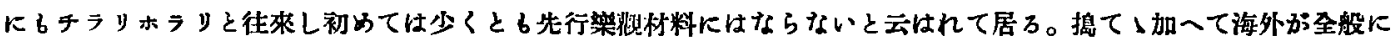

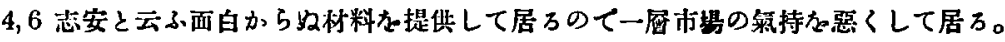

東 宗市況

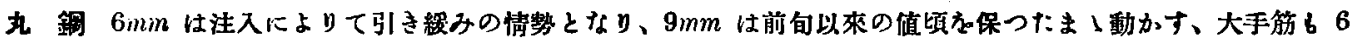

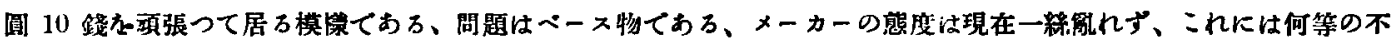

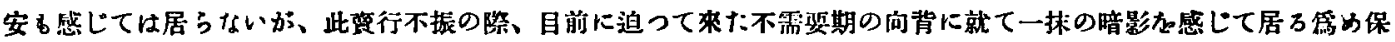

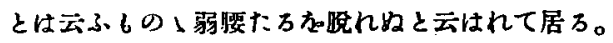

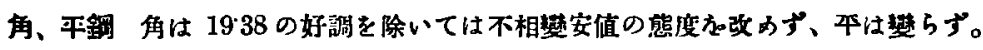

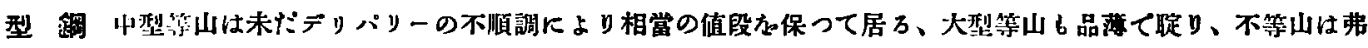

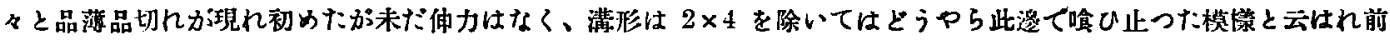

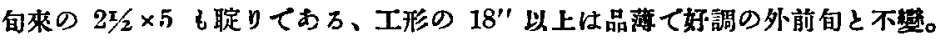

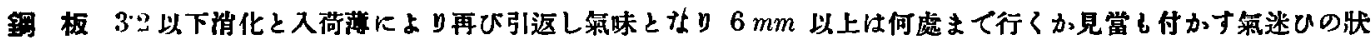
態か楼けて居万。

大 阪 市 況

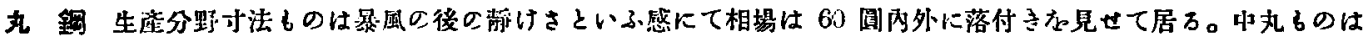

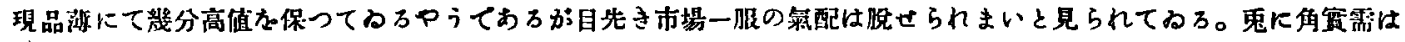

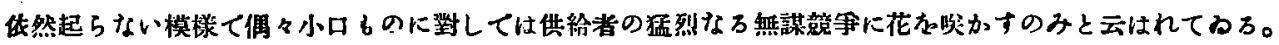

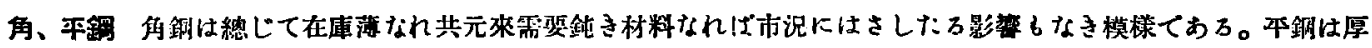

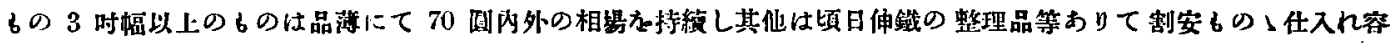

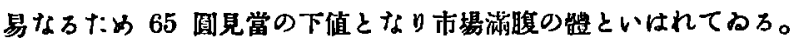

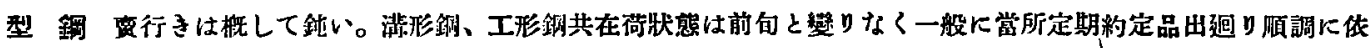

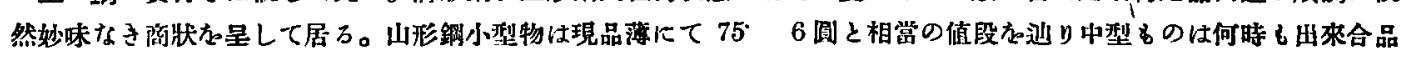

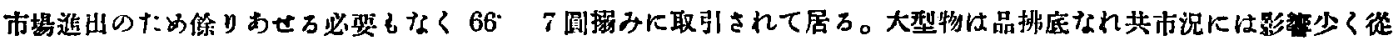
つて相埸し釗付け化されて面白味にそしい。

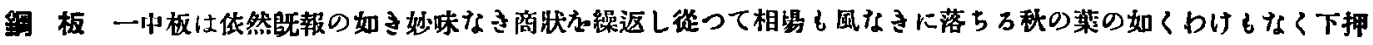

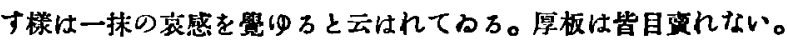

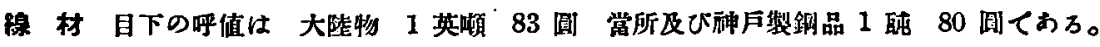

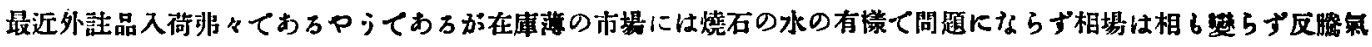
勢わ改めず遂に製品安に原料高の奇現象か星するにいたつた。鬼に角、既報の如くこの高相場に調子ういて秋風にあ

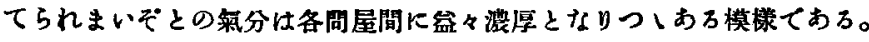

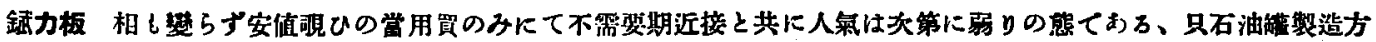




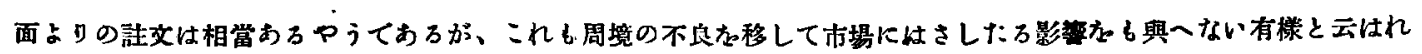
てらる。

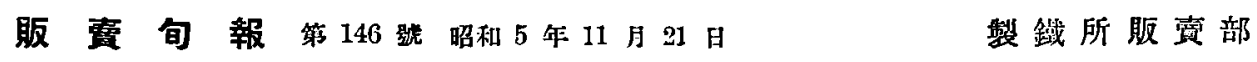
契約品の引取遲滯及皘出幄延の處理に關し追加 去万 10 月 8 日の 11 、12 月渡先物咕議會に於て決定せ

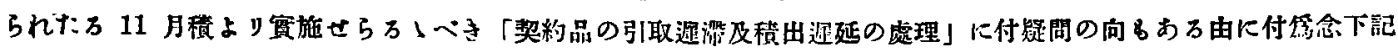
を末抟に追加す。

下記 4、規格品、官然用品には當分の队適㛄せす。

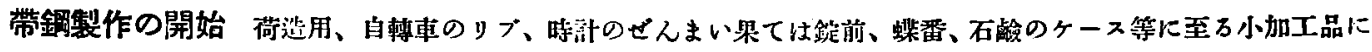

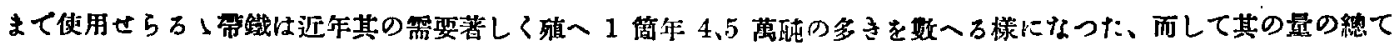

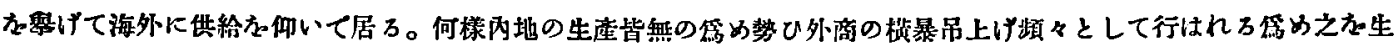

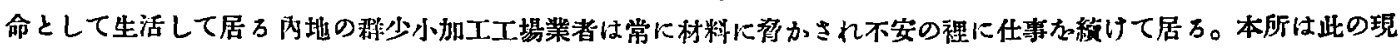

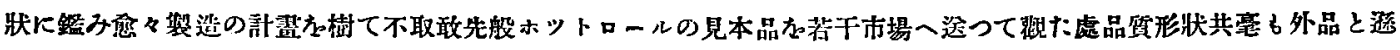

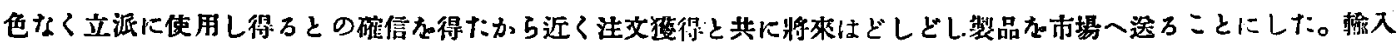

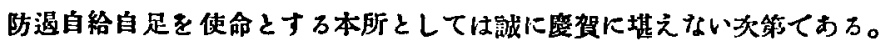

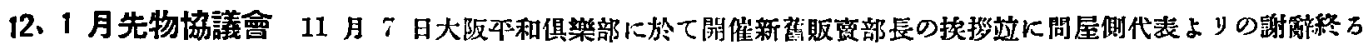

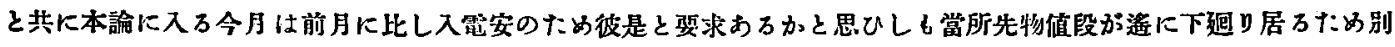

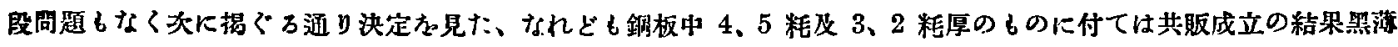

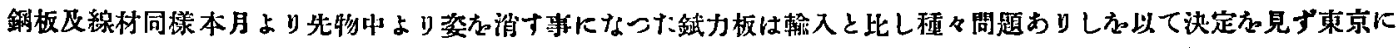
持越し解決するに決定。

\section{2、1 月積先物協議會}

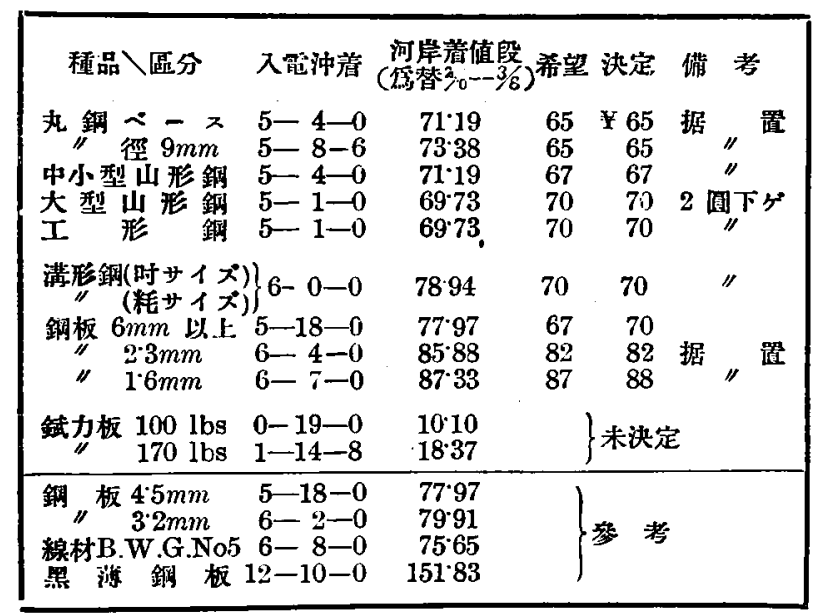

日本黑板共販理事會 12 月栍に關する 理事會は 15 日東京丸, 合合觹に開催。 1) 12 月積㾞出植

㐫地向 9,000 䣩 輸出向 3,000 础 計 12,000 陆 前月に比し內地向真出は 1,000 矿減とした: 譯ておる。

此数量に開しては色々の議諭し出て共贩自 ら資出数量え減ずるは市場一悲非の材料々提 供するのてはおるまいかとし云はれだが、先

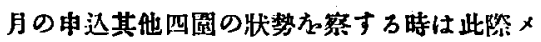
一カーが自發的に慎重の態度に出てろ方が市

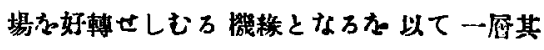
好果古得万管次の條件の下に此数量之決定し た。

a、內地向は 9,000 䣩以上は絕對に引受け

ざること b、積出前の荷波は如何なる理由おるる是か受付けさること

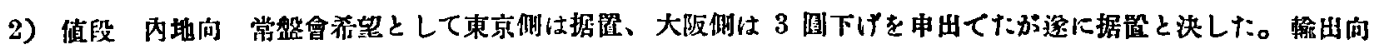

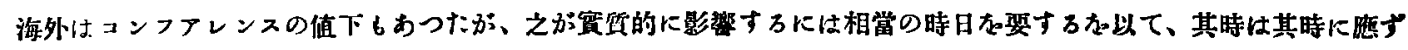

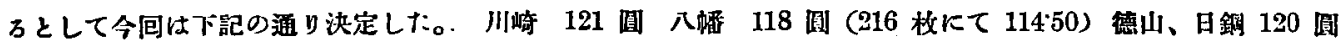

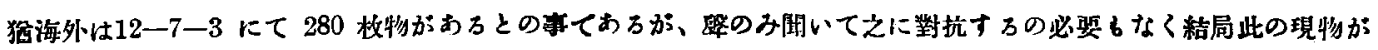
入奇してから策が满ずることに決定した。

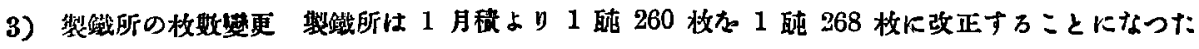

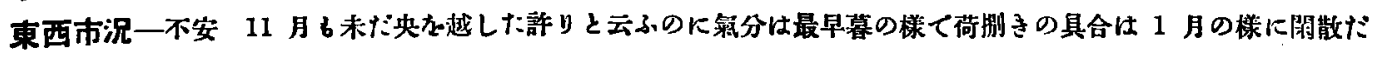

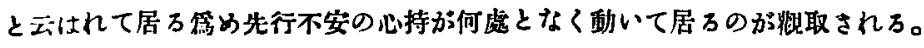


從つて相場としては如何に品掠れ物ても環境に押されて反撥のカるなく、それに一般が斯ふ永く損許り維くと僻か。

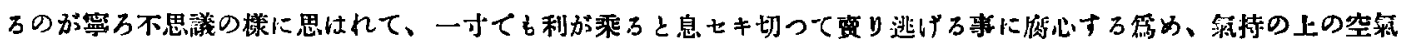

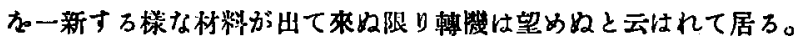

東 京市 況

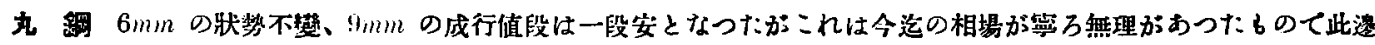

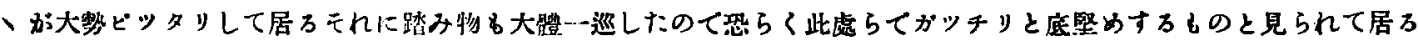

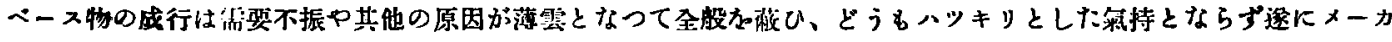

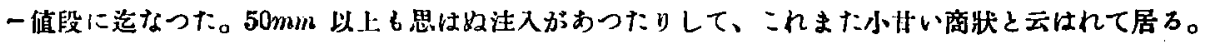

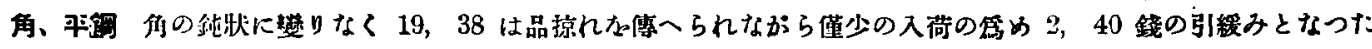

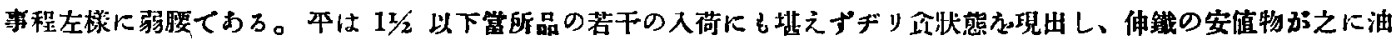

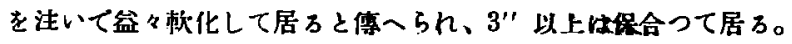

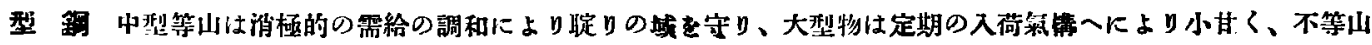

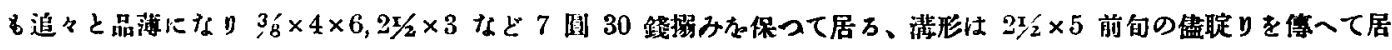

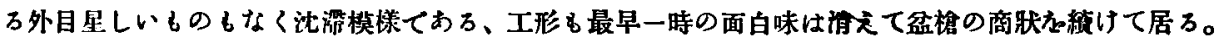

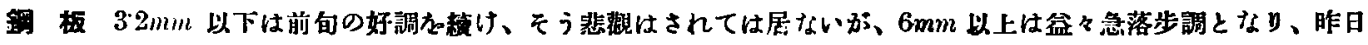

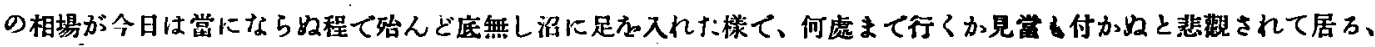
何とかせずはなるまいと云はんて居る。

大阪 市 況

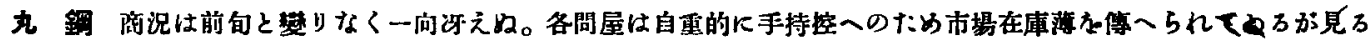

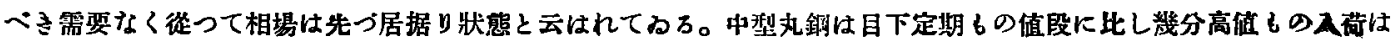

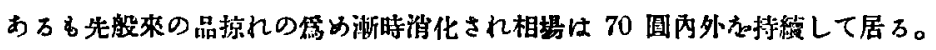

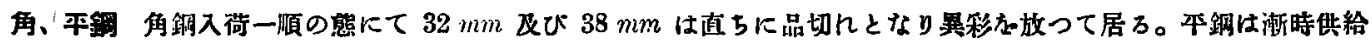

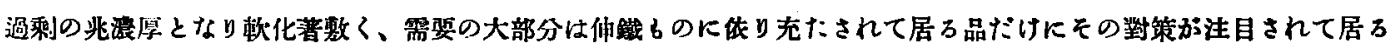

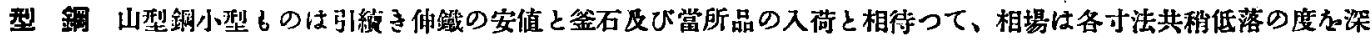

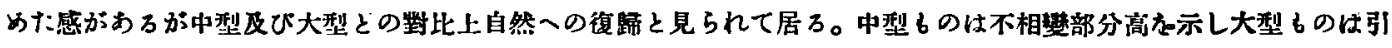

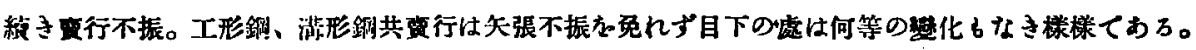

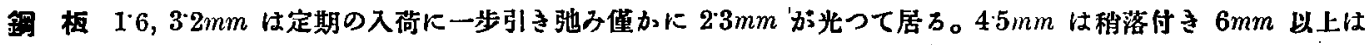
今绱湿沌たる有㥞と云はれて居る。

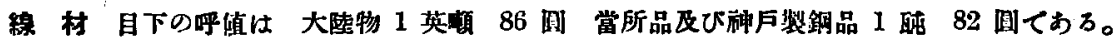

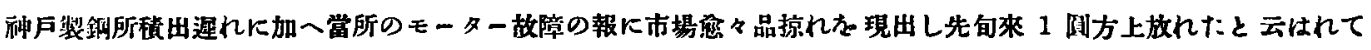

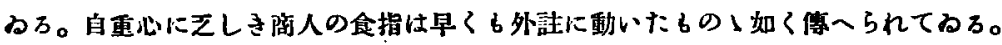

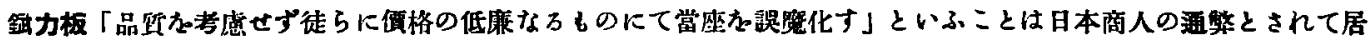

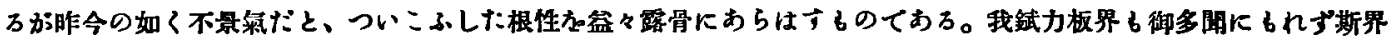

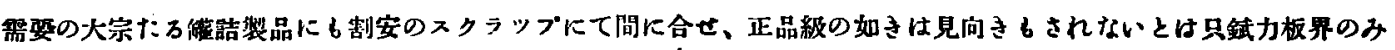

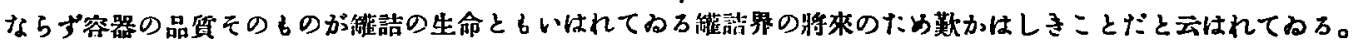

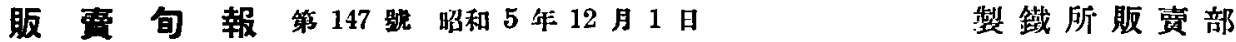

\section{過去 3 ケ年間の鋼材供給狀龍（其 4 ）}

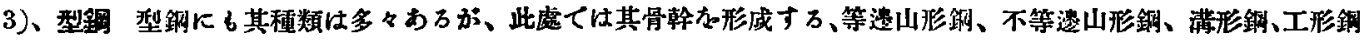

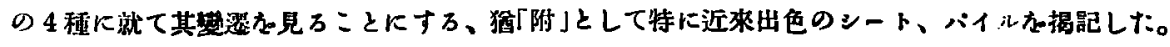

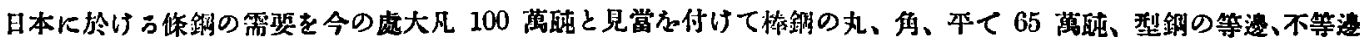

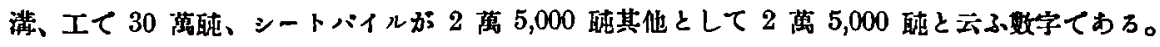

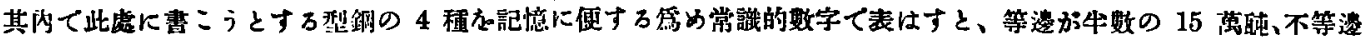

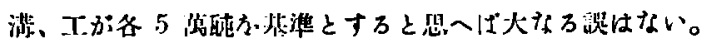


商

㫛

1347

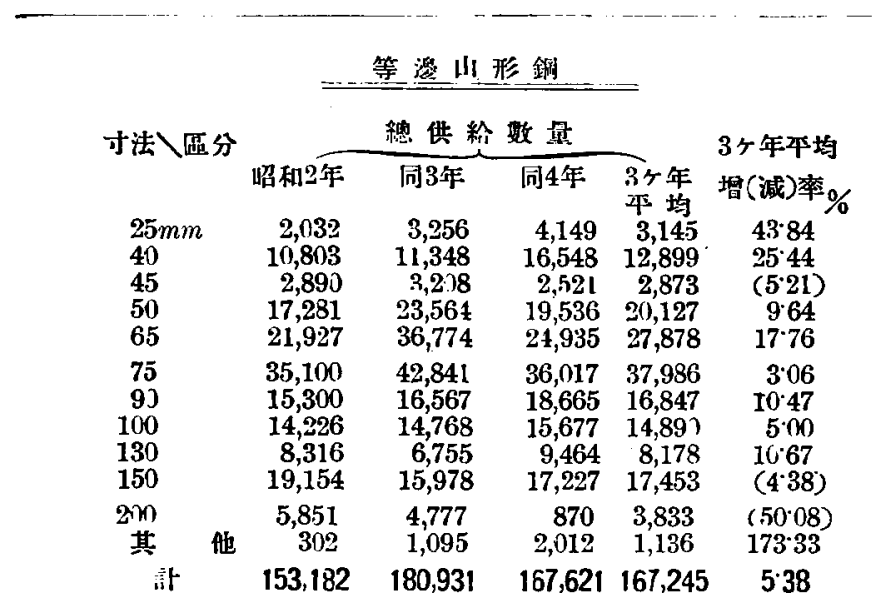

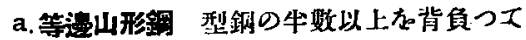

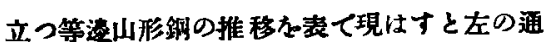

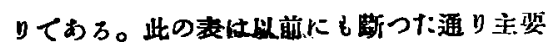
なろ代表的抾に聚的しだのて、此表ては 只の 12 才法にはつて居るが筫際に供給され た寸法は、昭和 4 年に於て、时寸法 15 種、粍寸 法にて 16 種合部 31 種の多伖に互つて居万。

また粍化が叫はれて可なり古いにし拘らす 昭和 4 年て胃万と时寸法が 11 营 3,482純に 對し耗寸法が 5 茧 4,439 砘て、未だ未ド时寸 法が粔寸法の傍以上の影客を持つて居乃、粔 化の前途 b亦传遠てお万。

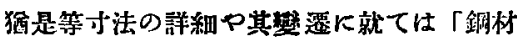

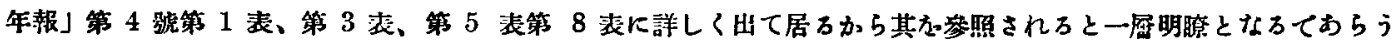

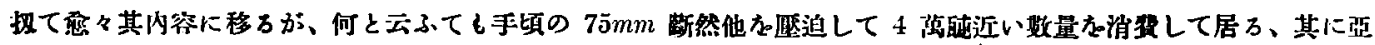

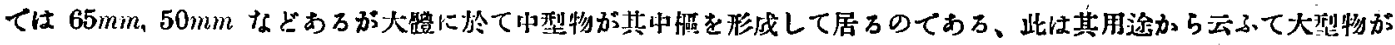

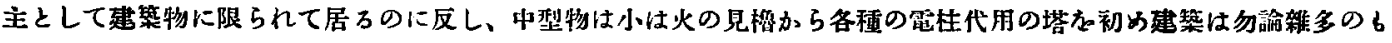

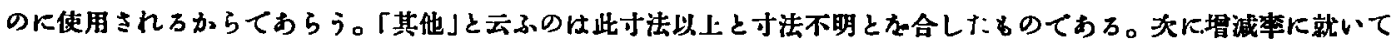

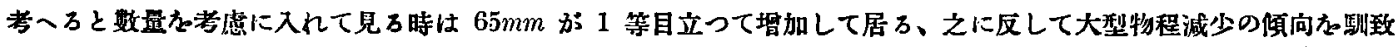

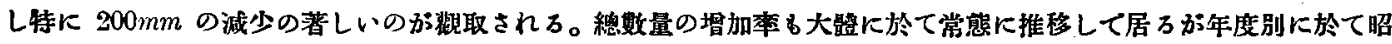

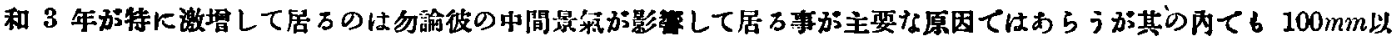

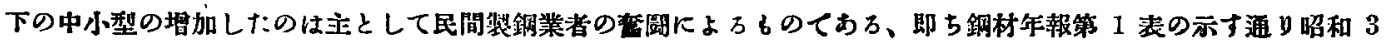

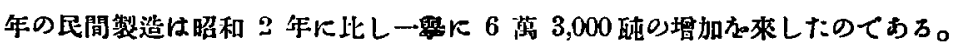

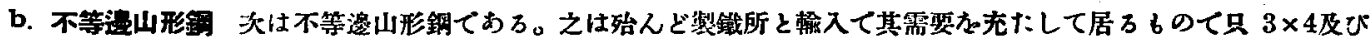

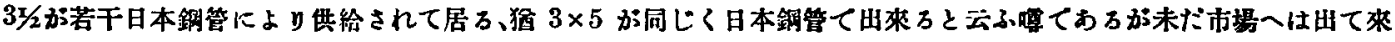
ない模样ておろ。

不等灙山形銅

\begin{tabular}{|c|c|c|c|c|c|}
\hline \multirow[b]{2}{*}{ 寸法】區分 } & \multicolumn{4}{|c|}{ 不等澺山形銅 } & \multirow{3}{*}{$\begin{array}{l}3 \text { ヶ 年 } \\
\text { 平均 } \\
\text { 堌(娍)來 }\end{array}$} \\
\hline & \multicolumn{4}{|c|}{ 總供給数擂 } & \\
\hline & 2 年 & 同 3 年 & 同 4 年 & $\begin{array}{l}3 \text { ヶ年 } \\
\text { 平均 }\end{array}$ & \\
\hline 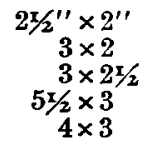 & $\begin{array}{l}1,410 \\
3,849 \\
1,398 \\
2,769 \\
7,736\end{array}$ & $\begin{array}{l}1,077 \\
1,917 \\
1,678 \\
1,400 \\
5,049\end{array}$ & $\begin{array}{r}2,083 \\
2,203 \\
2,415 \\
4,239 \\
11,295\end{array}$ & $\begin{array}{l}1,524 \\
2,656 \\
1,830 \\
2,800 \\
8,027\end{array}$ & $\begin{array}{c}34.89 \% \\
(17.64) \\
31 \cdot 98 \\
76.76 \\
44.49\end{array}$ \\
\hline $\begin{array}{l}5 \times 3 \\
5 \times 3^{1 / 2} \\
5 \times 4 \\
6 \times 3^{1 / 2} \\
6 \times 4\end{array}$ & $\begin{array}{r}6,382 \\
5,876 \\
443 \\
3,993 \\
8,333\end{array}$ & $\begin{array}{r}5,324 \\
4,698 \\
933 \\
1,906 \\
7,493\end{array}$ & $\begin{array}{l}8,843 \\
9,347 \\
1,128 \\
2,432 \\
8,565\end{array}$ & $\begin{array}{r}6850 \\
6,610 \\
835 \\
2,777 \\
8,130\end{array}$ & $\begin{array}{c}24 \cdot 76 \\
39 \cdot 46 \\
65 \cdot 76 \\
(1234) \\
2 \cdot 12\end{array}$ \\
\hline 其 地 & 1,206 & 1,481 & 890 & 1,192 & $(8 \cdot 69)$ \\
\hline 部 & 43,386 & 32,956 & 53,440 & 43,261 & 19.06 \\
\hline
\end{tabular}

3 ケ年を本均した合計は 4 萬 3,000 俆䣩 てお万、之と對比ナ万感的昭和 5 年上牛期な

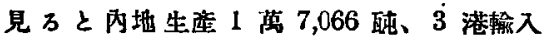

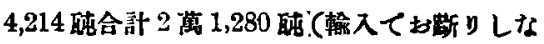

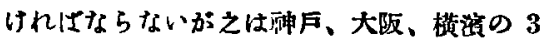
港合計て全國の翰入は之より、いくらかは㙕 加するておらう)、て下牛期い之と同滕と見て

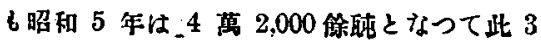
ケ年平均敗字とオツカッておちが、昭和 4 年 に比すれは 1 莗俆䣩の娍少となる。然し宽䟢 はつともつと減少して居万てあらうと云小 のは榡入けけても7月ょり 10 月迄の 4 ケ月 の 3 港合部が只の 516 䣩でるから或は 4

莴䣩以下には万のてはおろまいか。

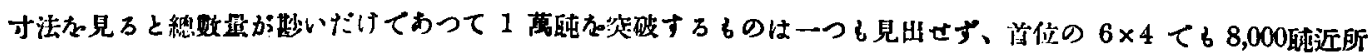

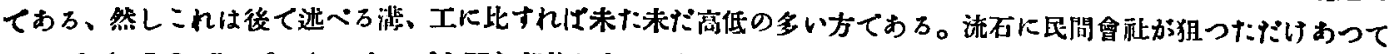

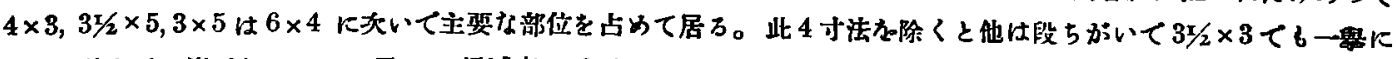

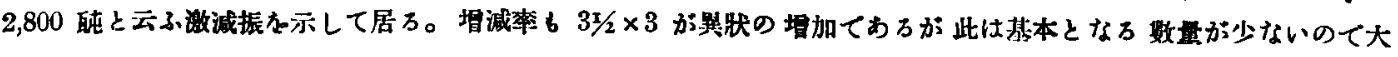


しだ事るはいが、前記の $4 \times 3,3 \times 2 \times 5$ 增加來 6目立つて多くなつたのておろ。

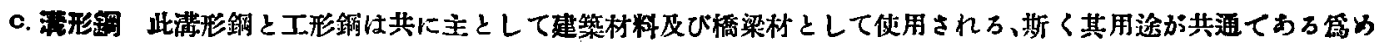
其趣答に於ても相似の點が多いのでう。

\begin{tabular}{|c|c|c|c|c|c|}
\hline \multirow{3}{*}{ 寸法】属分 } & \multicolumn{3}{|c|}{ 愺 形 鋼 } & & \multirow{3}{*}{$\begin{array}{l}3 \text { ヶ 年 } \\
\text { 平 }\end{array}$} \\
\hline & \multicolumn{4}{|c|}{ 總供 給数量 } & \\
\hline & 昭和 2 年 & 同 3 年 & 同 4 年 & $\begin{array}{l}3 \text { ケ年 } \\
\text { 平均 }\end{array}$ & \\
\hline $\begin{array}{l}3 / 2^{\prime \prime} \times 11 / 2^{\prime \prime} \\
4 \times 2 \\
5 \times 21 / 2 \\
6 \times 212 \\
6 \times 3\end{array}$ & $\begin{array}{l}1,296 \\
4,817 \\
\mathbf{3 , 4 7 1} \\
\mathbf{3 , 4 0 9} \\
\mathbf{7 , 3 6 5}\end{array}$ & $\begin{array}{r}931 \\
3,117 \\
5,165 \\
3,452 \\
4,498\end{array}$ & $\begin{array}{r}934 \\
3,183 \\
4,432 \\
2,899 \\
6,487\end{array}$ & $\begin{array}{l}1,044 \\
3,706 \\
4,359 \\
3,253 \\
6,117\end{array}$ & $\begin{array}{c}(13.41) \% \\
(16.59) \\
74.93 \\
(665) \\
264\end{array}$ \\
\hline $\begin{array}{c}7 \times 3 \\
8 \times 1 \\
8 \times 3 \\
9 \times 31 / 2 \\
10 \times 31 / 2\end{array}$ & $\begin{array}{l}3,103 \\
2,017 \\
2,953 \\
5,020 \\
6,503\end{array}$ & $\begin{array}{l}2,592 \\
2,210 \\
3,663 \\
3,316 \\
4,625\end{array}$ & $\begin{array}{l}1,811 \\
2,455 \\
3,263 \\
3,377 \\
7,391\end{array}$ & $\begin{array}{l}2,512 \\
2,227 \\
3,293 \\
3,904 \\
6,173\end{array}$ & $\begin{array}{c}(22.67) \\
0.76 \\
(0.27) \\
(16.07) \\
15.48\end{array}$ \\
\hline $\begin{array}{l}12 \times 31 / 2 \\
15 \times 4 \\
\text { 其 他 }\end{array}$ & $\begin{array}{l}2,676 \\
8,360 \\
4,228\end{array}$ & $\begin{array}{l}3,285 \\
2,432 \\
2,210\end{array}$ & $\begin{array}{l}\mathbf{5 , 9 9 3} \\
\mathbf{3 , 5 6 4} \\
\mathbf{1 , 3 5 3}\end{array}$ & $\begin{array}{l}3,986 \\
4,786 \\
2,597\end{array}$ & $\begin{array}{c}5268 \\
(1228) \\
(4325)\end{array}$ \\
\hline 该 & 55,218 & 41,466 & 47,177 & 47.954 & $(5.57)$ \\
\hline
\end{tabular}

此を㗬所のみの供給にては不充分て平均し

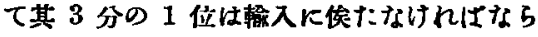
ない。それで統制力のない输入が年によつて 震蝠か大にするのて（銅材年埌第 1 裴、其 1、其 2、其 3、勢照)常に不安定に置加れて 居乃のは已もな得ない狀㫛ておろ。

即与昭和 3 年に於け万棒銅其他方所謂山

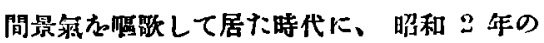
過剩輸入に㨫まされて悲鸣を學げ涉、工は山 形と板に代用される侯向になつたのて將來紫 みないとまて云けれたが、此度は逆に昭和４ 年は前年の極端な輸入減により（數量は年垠 第 1 装其 2 疼照) スッカy調子付き、棒銅

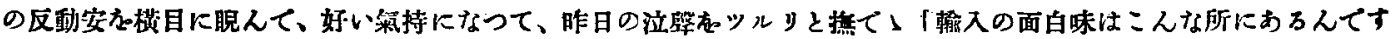

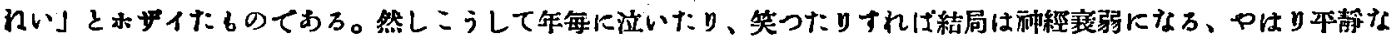

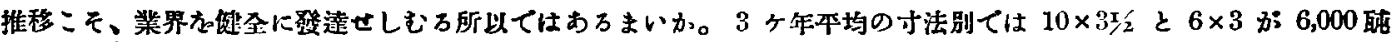

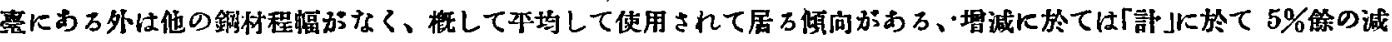
になつて居っがこれは炤和 2 年の供給數量異狀に多きに過ぎた事る考虑に入れなければならないと思ふ。各寸法の 㙕滅の著しいのも思惑翰入の崇りと考二られろ。

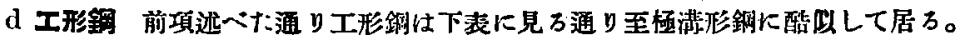

\begin{tabular}{|c|c|c|c|c|c|}
\hline \multirow[t]{2}{*}{ 才法】區分 } & \multicolumn{4}{|c|}{ 總供給数量 } & \multirow{2}{*}{$\begin{array}{l}3 \text { ヶ 年 } \\
\text { 平均 } \\
\text { 㙕(娍)雮 }\end{array}$} \\
\hline & 炤和 2 年 & 同 3 年 & 同 4年 & $\begin{array}{l}3 \text { 年 } \\
\text { 平均 }\end{array}$ & \\
\hline $\begin{array}{c}4^{\prime \prime} \times 3^{\prime \prime} \\
6 \times 3 \\
7 \times 4 \\
8 \times 4 \\
9 \times 4\end{array}$ & $\begin{array}{l}1,1,61 \\
2,968 \\
2,253 \\
1,802 \\
3,197\end{array}$ & $\begin{array}{r}636 \\
\mathbf{3 , 5 8 6} \\
\mathbf{3 , 3 3 9} \\
\mathbf{3 , 5 3 9} \\
\mathbf{3 , 4 8 9}\end{array}$ & $\begin{array}{l}1,040 \\
2,377 \\
3,186 \\
3,290 \\
4,518\end{array}$ & $\begin{array}{r}912 \\
2,977 \\
2,923 \\
2,877 \\
3,735\end{array}$ & $\begin{array}{l}11 \cdot 73 \% \\
(645) \\
21 \cdot 74 \\
44 \cdot 68 \\
19 \cdot 31\end{array}$ \\
\hline $\begin{array}{l}10 \times 5 \\
10 \times 5 \\
12 \times 6 \\
14 \times 6 \\
16 \times 6\end{array}$ & $\begin{array}{l}4,339 \\
5,887 \\
5,904 \\
1,777 \\
7,292\end{array}$ & $\begin{array}{l}\mathbf{4}, 461 \\
\mathbf{3}, 240 \\
\mathbf{3}, 858 \\
\mathbf{1}, 329 \\
\mathbf{3}, \mathbf{3 7 1}\end{array}$ & $\begin{array}{l}2,864 \\
7,039 \\
8,505 \\
2,200 \\
3,773\end{array}$ & $\begin{array}{l}3,888 \\
5,389 \\
6,089 \\
1,769 \\
4,812\end{array}$ & $\begin{array}{c}(16.50) \\
36.15 \\
42911 \\
20.17 \\
(20.92)\end{array}$ \\
\hline $\begin{array}{l}18 \times 7 \\
20 \times 71 / 2 \\
24 \times 71 / 2 \\
\text { 其 他 }\end{array}$ & $\begin{array}{r}7,062 \\
3,589 \\
3,936 \\
919\end{array}$ & $\begin{array}{r}4,084 \\
2,905 \\
3,429 \\
444\end{array}$ & $\begin{array}{l}7,008 \\
2,800 \\
3,046 \\
2,580\end{array}$ & $\begin{array}{l}6,051 \\
3,093 \\
3,470 \\
1,314\end{array}$ & $\begin{array}{c}14.72 \\
(11.43) \\
(12.03) \\
215.20\end{array}$ \\
\hline it & 51,986 & 41,701 & 54,226 & 49,304 & $5 \cdot 14$ \\
\hline
\end{tabular}

先つ数量加ら云ふてい满形銅の 3年平坞の

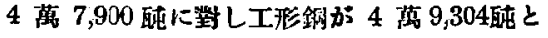
砝んど同じてある。

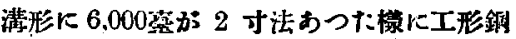
6 $12 \times 6$ と $18 \times 7$ の 2 寸法がゃはり 6,000

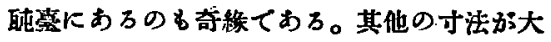
なる開きが認められなく平均して居ることい 做て居万。

年别の「計」て。昭和 2 年が甚しく多い事 次年がまた著しく減少して、昭和 4 年㙕加

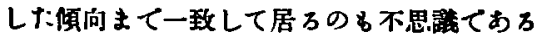
未げ相似の點か求め万と才法别の堽減 b $16 \times 6$ が $20 \%$ も減じて居ると思へば $12 \times 6$ が $42 \%$ 6㙕して居ろ栐に各寸法比較的大き な增隇え示して居ろなど㴖形銅と酷似して居

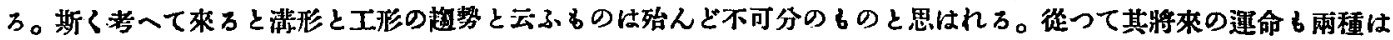

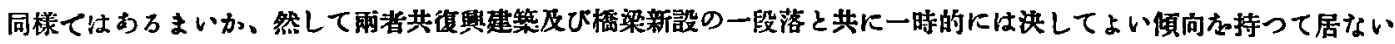

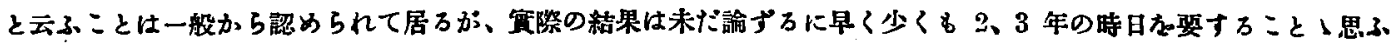

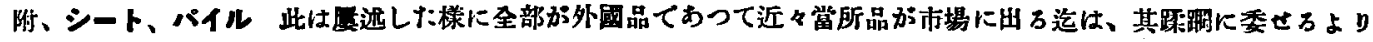

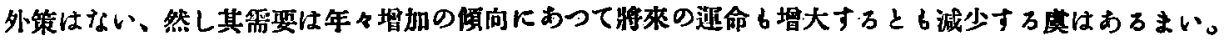

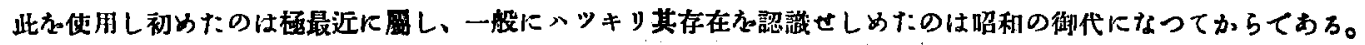


どんな具合に增加したか、鋼材年報第 1 表、其 1 、其 2 、其 3 から拾って見ると

昭和 2 年 昭和 3 年 昭和 4 年 3 年平均 昭和 5 年(皇 10 月肙三港)

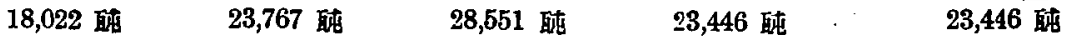

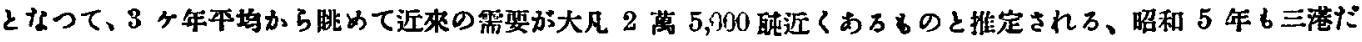

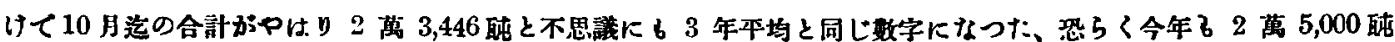

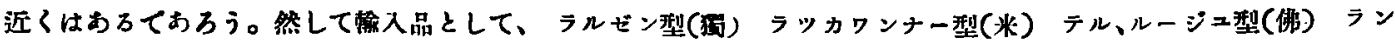

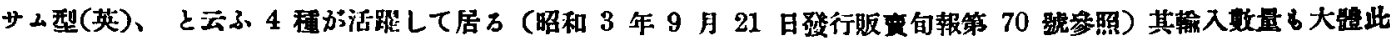

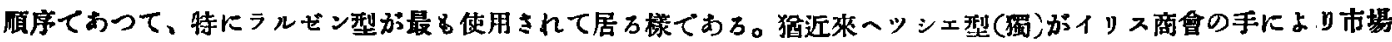
К進出して來たと云恃れて居ろ。

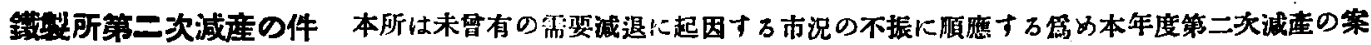

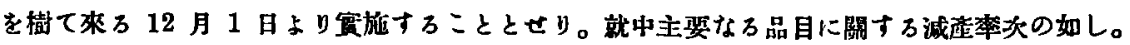

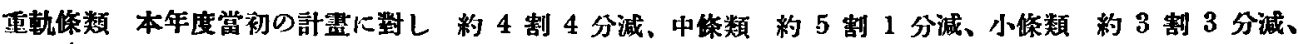

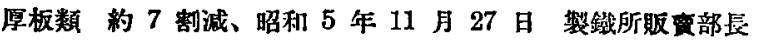

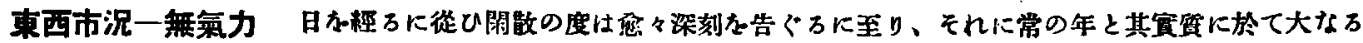

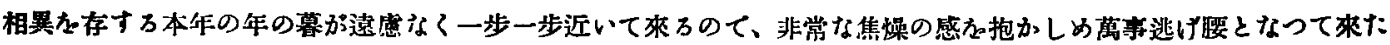
と見られて居万。特に厚板の崩落は釗枋界全般に不安の影を投げたと云はれ此等荡氣材料が粽合されて平均して 1 、

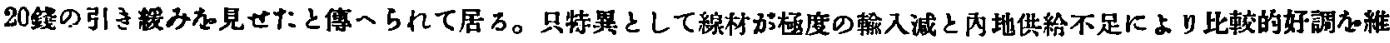

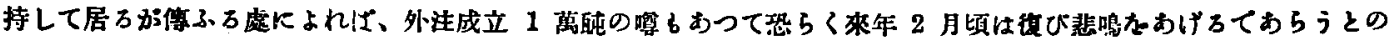

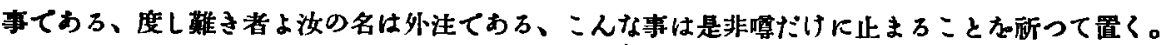

東 京市 況

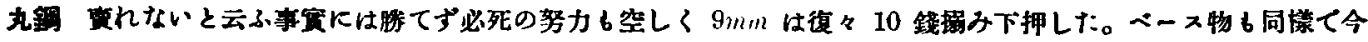

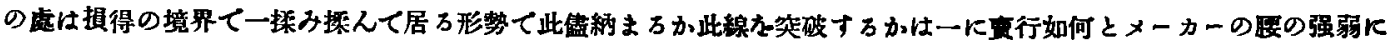

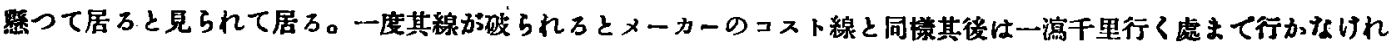
仕落ち着くまいと云はれて居る。

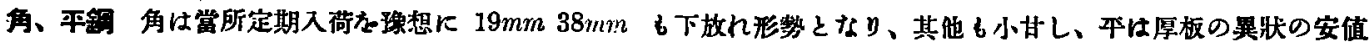

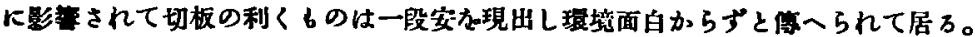

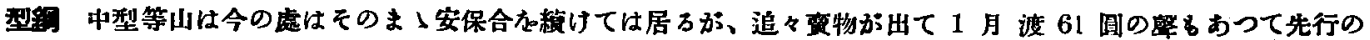

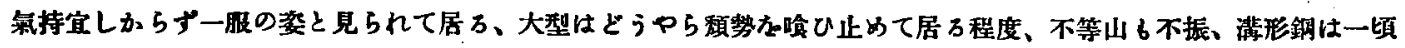

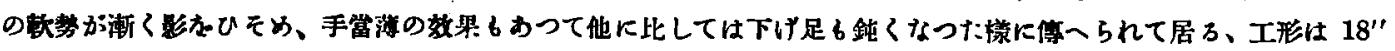

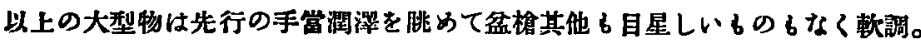

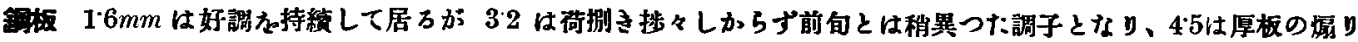

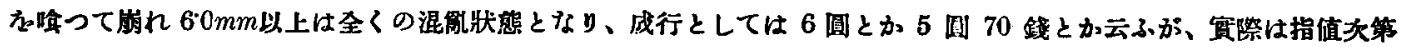

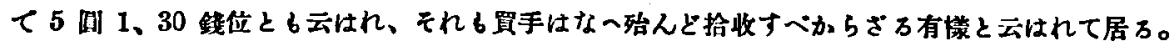

大阪市 況

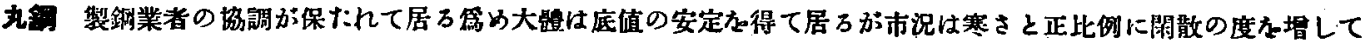

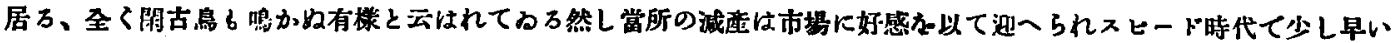
が來春わ樂みにさられてるら栐子てある。

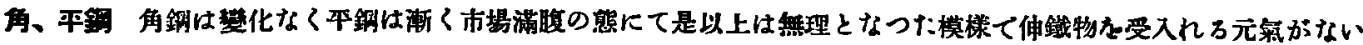

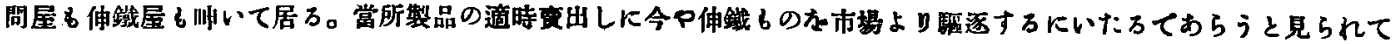
○っ。

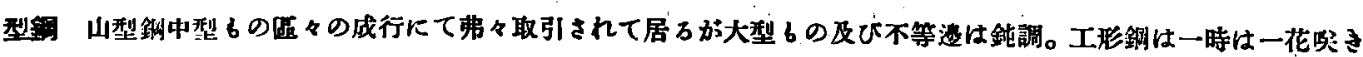

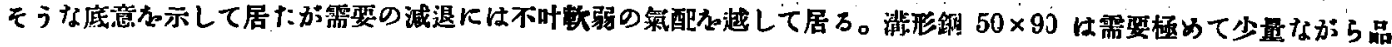

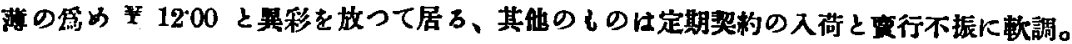

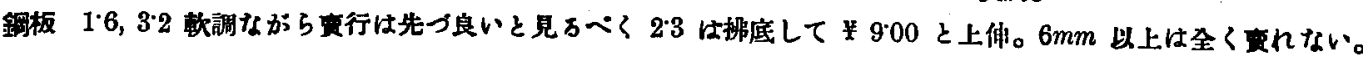


1350

鐵と鋼 第一・六年 第十二號

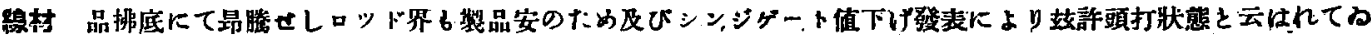
万。

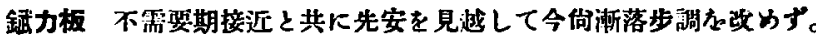

\section{1 月上中下旬線材薄板鐡力板輸入速報}

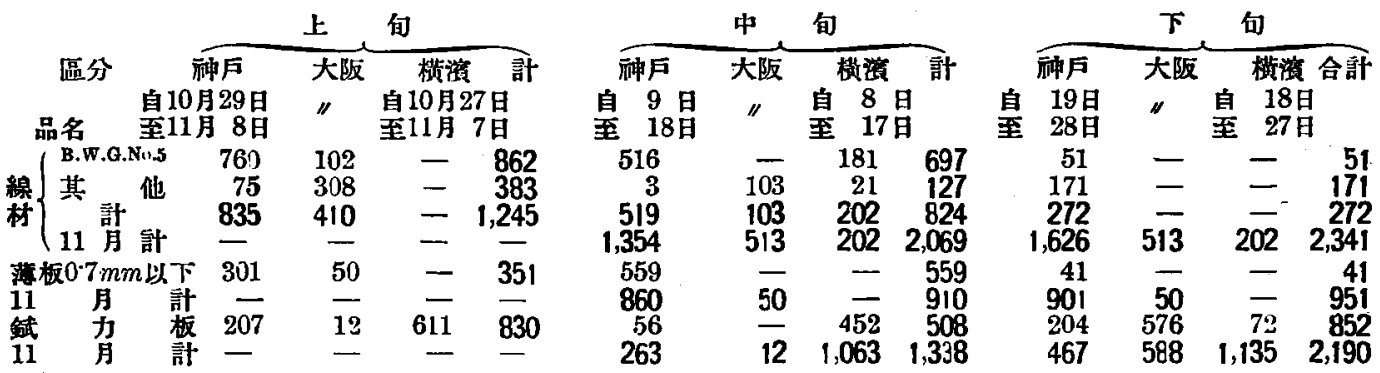

\section{東 京大阪 市中相 場}

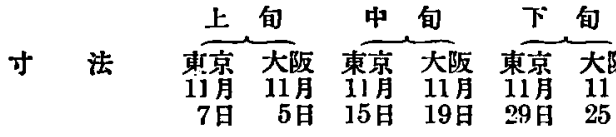

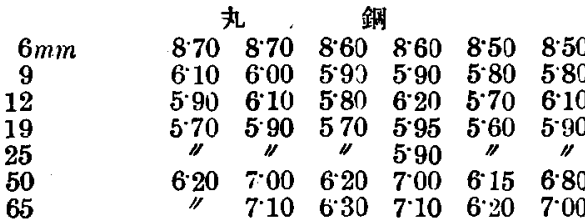

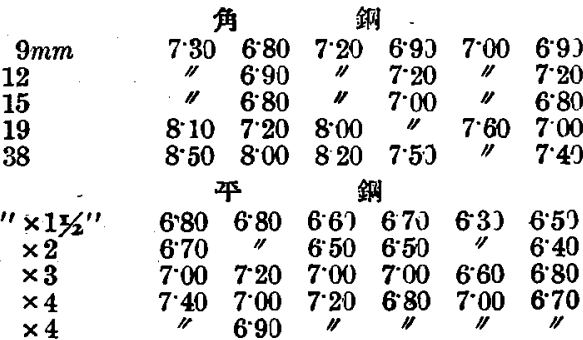

等 济山形銅

\begin{tabular}{|c|c|c|c|c|c|c|}
\hline$\times 50 \times 50$ & $\underset{N}{6.60}$ & $\begin{array}{l}690 \\
700\end{array}$ & $6 \underset{y}{60}$ & & & \\
\hline $\begin{array}{l}5 \\
130 \\
130\end{array}$ & $\begin{array}{l}6.50 \\
780 \\
8.00\end{array}$ & $\begin{array}{l}6.60 \\
7.50 \\
7.60 \\
7.50\end{array}$ & $\begin{array}{l}6.50 \\
7.30 \\
7.50 \\
7.40\end{array}$ & $\begin{array}{c}6.50 \\
730 \\
" 1 \\
" 1\end{array}$ & $\begin{array}{c}740 \\
" 11 \\
"\end{array}$ & \\
\hline \multicolumn{7}{|c|}{ 不等港山形鵭 } \\
\hline $\begin{array}{l}l^{\prime \prime} \times 3^{\prime \prime} \\
\times 4 \\
2 \times 5\end{array}$ & $\begin{array}{l}7 \cdot 20 \\
6 \cdot 60 \\
670\end{array}$ & $\begin{array}{l}7 \cdot 20 \\
6 \cdot 70 \\
6 \cdot 80 \\
7 \cdot 50\end{array}$ & $\begin{array}{l}7 \cdot 30 \\
6 \cdot 50 \\
6 \cdot 70 \\
7 \cdot 20 \\
7 \cdot 60\end{array}$ & $\begin{array}{c}7 \cdot 10 \\
6 \cdot 60 \\
/ 1 \\
7 \cdot 30 \\
/ 1\end{array}$ & $\begin{array}{l}7 \cdot 20 \\
6 \cdot 40 \\
6 \cdot 60 \\
7 \cdot 20 \\
7 \cdot 50\end{array}$ & \\
\hline
\end{tabular}

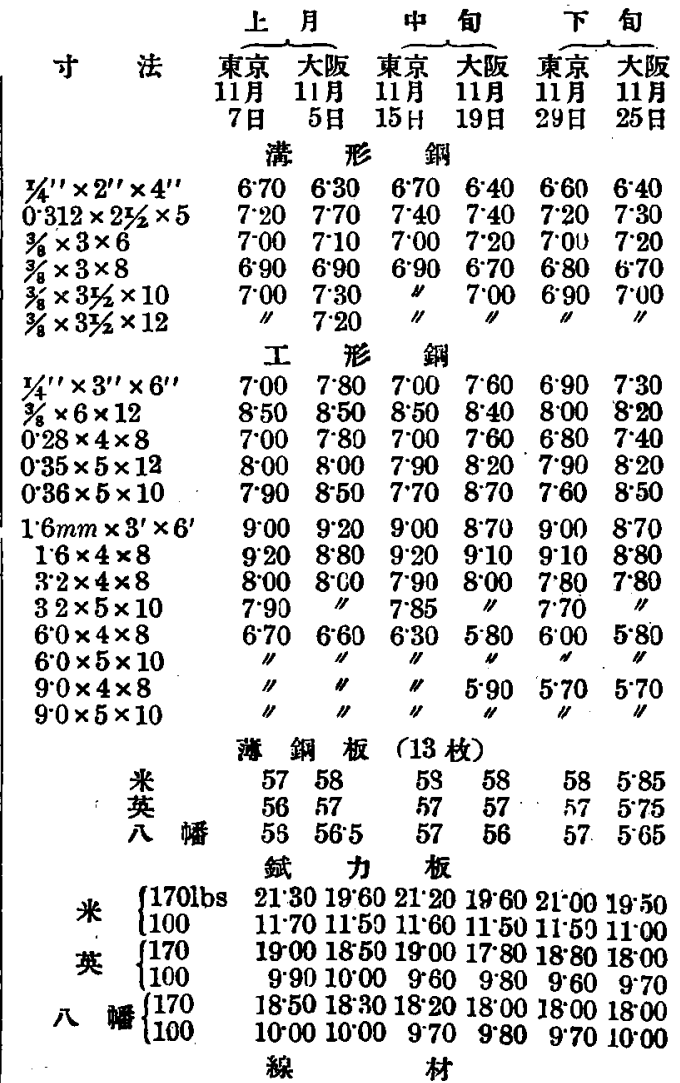

No. $5 \quad 81 \cdot 0080.0082 \cdot 5082 \cdot 0081 \cdot 5081 \cdot 00$

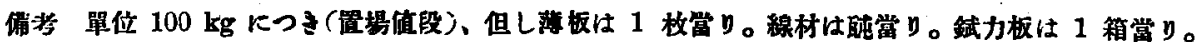


昭和 5 年 9 月中國別签入數量表 單位䣩

\begin{tabular}{|c|c|c|c|c|c|c|c|c|c|c|c|c|c|}
\hline 嵒 種 國 別 & 英 & 佛 & 濁 & 白 & 墺 & 和 & 典 & 合 & 關 & 印 & 其他 & 壾 & 年 \\
\hline 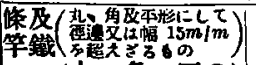 & 41 & -1 & 99 & 117 & 89 & 123 & 35 & 18 & - & - & -- & 1,422 & 9,1 \\
\hline 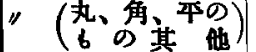 & 202 & 105 & 1,176 & 38 & 20 & 10 & 27 & 381 & - & - & 9 & 1,968 & 3.86 \\
\hline 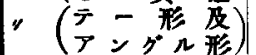 & 548 & 24 & 132 & $15 \mathrm{c}$ & - & - & - & - & - & - & - & 854 & 8,6 \\
\hline （其 & 15 & 25 & 503 & 40 & - & - & - & 5 & - & - & 2 & 590 & 0,13 \\
\hline$\nu .-$ & - & - & 186 & 一 & - & - & - & 258 & - & - & - & 444 & 1,01 \\
\hline プッシプレート & - & - & 3 & - & - & - & - & - & 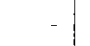 & - & - & 3 & \\
\hline 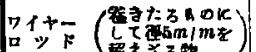 & - & - & - & - & - & - & - & - & - & - & -1 & - & 1,02 \\
\hline " & 1 & 855 & 2,105 & 27 & 51 & - & 43 & 1,292 & - & - & - & 4,629 & 59.12 \\
\hline 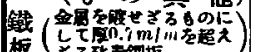 & 1 & - & $6 ?$ & - & 10 & - & 66 & 299 & - & - & - & 358 &, 70 \\
\hline 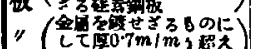 & 606 & - & 139 & - & -1 & - & - & 104 & - & - & 6 & 849 & 25,82 \\
\hline " & ]. & 51 & 323 & 228 & - & 77 & 25 & $1 \pm 9$ & - & - & - & 854 & $0, \angle 0$ \\
\hline 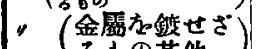 & 1,540 & - & 416 & 66 & - & - & 2 & 137 & - & - & - & 2,161 & 36,66 \\
\hline (錫銥 & 1.626 & - & 13 & - & - & - & - & 2,157 & - & 一 & 104 & 3,900 & 58,58 \\
\hline 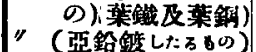 & 31 & - & - & - & - & - & - & 122 & - & - & 69 & 222 & ,86 \\
\hline (基他告金成各) & - & - & 一 & - & - & - & - & 1 & - & - & - & 1 & \\
\hline 9) & 32 & -1 & 77 & 13 & 2 & - & 9 & 36 & - & - & - & I69 & 026 \\
\hline$y-\kappa \nabla 1+-\mid$ & - & 1 & - & - & - & -1 & - & -1 & - & - & - & 1 & \\
\hline y & 57 & - & 137 & 8 & - & - & 11 & 2 & - & - & - & 215 & \\
\hline 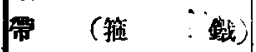 & 20 & 428 & 700 & 188 & - & - & - & 1 & 1 & -1 & - & 1.338 & 33,29 \\
\hline パラチン・ワイヤー & - & - & - & - & - & $\rightarrow$ & - & - & -- & - & - & - & 3 \\
\hline & 24 & - & 14 & -1 & - & -1 & - & 1 & - & - & - & 39 & \\
\hline 合 & - & -1 & 一 & - & - & - & - & 2 & $\longrightarrow$ & - & - & 2 & \\
\hline 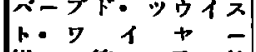 & 12 & - & - & - & - & -- & -1 & - & - & - & - & - & \\
\hline 筒 及 管 & 134 & 90 & 282 & - & - & - & - & 1,171 & - & - & 22 & 1,699 & 24,95 \\
\hline 特 殊 銅 稆表一) & 19 & - & 9 & - & 52 & - & 4 & 10 & 14 & - & 4 & 112 & ,6 \\
\hline " (梲表二) & 4 & - & 2 & - & 11 & - & 2 & - & - & -1 & - & 19 & 1,1 \\
\hline 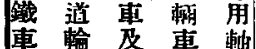 & - & - & - & - & - & - & - & 24 & - & - & - & 24 & $19 k$ \\
\hline 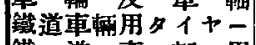 & - & - & 8 & - & - & - & - & - & - & - & - & 8 & 468 \\
\hline 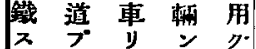 & - & - & - & - & - & -1 & - & - & - & - & - & - & \\
\hline 合 計 & 4.902 & 1,579 & 7,280 & 1,125 & 235 & 210 & 229 & 6,100 & 15 & - & 216 & 21,891 & 371,523 \\
\hline 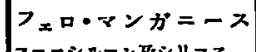 & - & - & - & - & - & - & - & - & - & - & - & & $0<$ \\
\hline 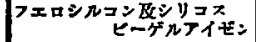 & - & - & - & - & -1 & -1 & -1 & - & - & - & - & -1 & \\
\hline 基 他 9 不 可 & - & - & 4 & - & - & - & 12 & - & 5 & - & 3 & 24 & 46 \\
\hline 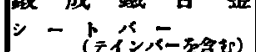 & - & 777 & 1,794 & - & - & - & - & 1,321 & - & - & - & 3,892 & 56,554 \\
\hline 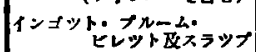 & - & - & 308 & - & - & - & - & - & - & - & - & 308 & 6,70 \\
\hline 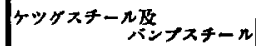 & - & - & - & - & -1 & - & 38 & - & - & - & - & 28 & 3 \\
\hline 他の塊及鉃较 & & - & - & - & - & - & - & - & - & - & - & - & \\
\hline 舍 & - & 777 & 2,106 & - & - & -1 & 40 & 1,321 & 5 & - & 3 & 4,252 & 65,711 \\
\hline 故 践 & $\begin{array}{r}81 \\
642\end{array}$ & - & $\overrightarrow{01}$ & $\overline{101}$ & $\overline{-}$ & -1 & 508 & 9,066 & $\begin{array}{l}4.351 \\
2250\end{array}$ & $\begin{array}{r}13,181 \\
3,545\end{array}$ & $\begin{array}{l}1,951 \\
8,264\end{array}$ & $\begin{array}{l}0,072 \\
4,069\end{array}$ & \\
\hline
\end{tabular}


昭和 5 年 10 月中神戸,大阪、横濱三港輸入鋼材品種寸法别數量表（其一（單位䣩）

\begin{tabular}{|c|c|c|c|c|c|c|c|c|c|c|c|}
\hline 寸 法 & 䣩 数 & 寸 法 & 䣩 數 & 寸法 & 旡 数 & 寸 法 & 䣩 酷 & 寸 法 & 䣩 & 寸 法 & 䎲 \\
\hline \multicolumn{2}{|c|}{ 捙闻の部 } & 角 & 鍂 & \multicolumn{2}{|c|}{ 型琱の部 } & \multirow{3}{*}{$\begin{array}{l}m m \quad m m \\
165 \times 75 \\
180 \times 90 \\
200 \times 75\end{array}$} & \multirow{2}{*}{$\begin{array}{l}20 \\
16\end{array}$} & \multirow{2}{*}{$\begin{array}{l}17 \\
19\end{array}$} & \multirow{2}{*}{$\begin{array}{l}5 \\
\mathbf{3} \\
4\end{array}$} & \multicolumn{2}{|c|}{ 緗杜 $の$ 部 } \\
\hline 九 & 鋼 & 3,161 & 11 & \multicolumn{2}{|c|}{ 等還山形琱 } & & & & & \multirow{5}{*}{ 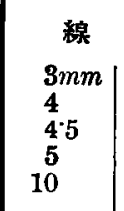 } & 籿 \\
\hline 361 & 66 & $\begin{array}{l}1.4 \\
516\end{array}$ & $\begin{array}{l}3 \\
\mathbf{3}\end{array}$ & $3.4^{\prime \prime}$ & 44 & & 35 & $\begin{array}{l}1.5 \\
1.7\end{array}$ & $\begin{array}{l}71 \\
30\end{array}$ & & \\
\hline $\begin{array}{l}1 / 32 \\
1 / 4\end{array}$ & $\begin{array}{l}1 \\
8\end{array}$ & 38 & 8 & 1 & 22 & 許 & 352 & 2 & 10 & & \\
\hline $5 / 16$ & 5 & 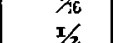 & $\begin{array}{l}4 \\
9\end{array}$ & 1,2 & 20 & 工 形 & & 22 & 15 & & 353 \\
\hline $\begin{array}{l}968 \\
7 / 2\end{array}$ & 2 & $9 / 16$ & 3 & & 106 & $\begin{array}{l}\times 4 \times 2 \\
12 \times 5\end{array}$ & $\begin{array}{l}5 J \\
19\end{array}$ & 其 & $\begin{array}{l}21 \\
10\end{array}$ & & $\mathbf{3}$ \\
\hline $\begin{array}{l}760 \\
1 / 2\end{array}$ & 9 & $\begin{array}{l}5 / 8 \\
1 / 16\end{array}$ & $\begin{array}{r}16 \\
3\end{array}$ & 造船才 & 外料 & $20 \times 6 / 4$ & 501 & 計 & 1,165 & $\begin{array}{l}\text { N.G.No.6 } \\
5\end{array}$ & $\begin{array}{r}358 \\
2,479\end{array}$ \\
\hline$\frac{58}{3 / 4}$ & $\begin{array}{l}6 \\
4\end{array}$ & $3 / 4$ & 14 & $2^{\prime \prime}$ & 2 & 計 I & 250 & 沿船才 & 材料 & & 11 \\
\hline $\begin{array}{l}7.4 \\
13 \\
316\end{array}$ & $\begin{array}{l}+ \\
2\end{array}$ & $1^{7 / 8}$ & $\begin{array}{l}9 \\
4\end{array}$ & $\begin{array}{l}3 \\
3^{1 / 2}\end{array}$ & $\begin{array}{r}19 \\
2\end{array}$ & 满 形 & 銅 & '帕" & 6 & $\begin{array}{l}2 \\
1\end{array}$ & $\begin{array}{r}9 \\
80\end{array}$ \\
\hline $7 / 8$ & $\begin{array}{l}6 \\
9\end{array}$ & $11 / 4$ & 3 & $\frac{4}{4}$ & 1 & $\left|\begin{array}{c}5^{\prime \prime} \times 1.751 \prime \\
10 \times 26\end{array}\right|$ & $\begin{array}{l}30 \\
31\end{array}$ & $3 / 32$ & $\begin{array}{l}2 \\
8\end{array}$ & & 49 \\
\hline $11 / 8$ & $\begin{array}{r}9 \\
10\end{array}$ & $\begin{array}{l}1 / 2 \\
13 / 4\end{array}$ & $\begin{array}{l}4 \\
2\end{array}$ & $\begin{array}{l}5 \\
6\end{array}$ & $\begin{array}{l}8 \\
9\end{array}$ & $5^{\prime \prime}$ & $\begin{array}{l}30 \\
40\end{array}$ & 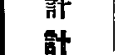 & $\begin{array}{r}8 \\
1,173\end{array}$ & $\begin{array}{l}00 \\
000\end{array}$ & $\begin{array}{r}178 \\
52\end{array}$ \\
\hline $\begin{array}{l}11 / 4 \\
13,8\end{array}$ & $\begin{array}{r}40 \\
7\end{array}$ & 2 & 8 & $75 \mathrm{~mm}$ & 5 & & 57 & 锹板 $(0.7 x$ & $m m$ 不 & & \\
\hline $11 / 2$ & 7 & $3^{21 / 2}$ & $\begin{array}{l}3 \\
2\end{array}$ & $\begin{array}{r}90 \\
100\end{array}$ & $\begin{array}{r}76 \\
4\end{array}$ & $\left|\begin{array}{lr}m m & m m \\
250 \times 100\end{array}\right|$ & 53 & | $8^{\text {sheets }}$ & 8 & 線村合訨 & 3,580 \\
\hline $\begin{array}{l}13 / 4 \\
13 / 4\end{array}$ & $\begin{array}{l}19 \\
10\end{array}$ & $\begin{array}{l}31 / 2 \\
4\end{array}$ & $\begin{array}{l}3 \\
3\end{array}$ & & 2 & 計 & 241 & $\begin{array}{l}10 \\
11\end{array}$ & $\begin{array}{r}520 \\
31\end{array}$ & 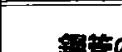 & 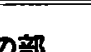 \\
\hline $\begin{array}{l}2 \\
2^{7 / 21}\end{array}$ & $\begin{array}{r}22 \\
8\end{array}$ & 5 & 4 & 180 & 10 & 造船才 & 材料 & \begin{tabular}{|l}
13 \\
B. W.G.
\end{tabular} & 23 & 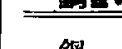 & 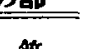 \\
\hline $21 / 4$ & 12 & $1^{7 m m}$ & 6 & 訽 & 143 & $\left|10^{\prime \prime} \times 4^{\prime \prime}\right|$ & 48 & 28 & $\begin{array}{r}20 \\
177\end{array}$ & 銅 & 管 \\
\hline 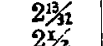 & 2 & 許 & 127 & 合 計 & 249 & $\begin{array}{l}2 \times 3 \times 3 \\
15 \times 4\end{array}$ & 70 & 30 & 1,010 & 畦' & 3 \\
\hline 258 & $\begin{array}{l}20 \\
10\end{array}$ & 平 & 鋼 & 不等魀 & I形鈎 & 計 & 126 & 計 & 1,789 & $\begin{array}{l}\frac{14}{3} 8 \\
3\end{array}$ & 15 \\
\hline $23 / 4$ & 14 & 4 & ting & $4=\times 3^{\prime \prime} \mid$ & 31 & 合 計 & 367 & 電氣 & 鐵板 & T/2 & $\begin{array}{l}90 \\
78\end{array}$ \\
\hline $\begin{array}{l}3 \\
3^{\prime} / 6\end{array}$ & $\begin{array}{r}14 \\
2\end{array}$ & 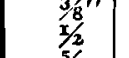 & 39 & 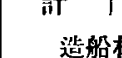 & 材料 & $\mathbf{T}$ 形 & & $\begin{array}{c}0.014^{\prime \prime} \\
0^{\circ} 017\end{array}$ & $\begin{array}{r}72 \\
153\end{array}$ & $1^{1 / 4}$ & 60 \\
\hline $\begin{array}{l}31 / 4 \\
3^{1 / 2}\end{array}$ & $\begin{array}{r}8 \\
11\end{array}$ & $\begin{array}{l}5 / 8 \\
3 / 4\end{array}$ & 29 & $5^{\prime \prime} \times 3^{\prime \prime}$ & 7 & $\left|\begin{array}{l}1^{\prime \prime} \times 11^{\prime \prime} \\
x / \times 1 x\end{array}\right|$ & 5 & $0.35 \mathrm{~mm}$ & 20 & $\begin{array}{l}11 / 4 \\
11 / 2\end{array}$ & $\begin{array}{l}95 \\
23\end{array}$ \\
\hline $33 / 4$ & 7 & $\%$ & 22 & $5 \times 3 \times 1 / 2$ & 10 & $\left|\begin{array}{ll}17 / 2 & \times 1 / 2 \\
n m & m m\end{array}\right|$ & & 05 & 15 & $13 / 4$ & 4 \\
\hline 4 & 9 & 1 & 14 & $6 \times 3 y_{2}$ & 2 & $135 \times 40$ & 12 & 許 & 260 & 2 & 29 \\
\hline $44^{1 / 4}$ & 8 & $\begin{array}{l}11 / 4 \\
11 / 2\end{array}$ & $\begin{array}{r}4 \\
16\end{array}$ & $7 \times 31 / 2$ & 1 & 訫 & 22 & 縞 銗 & 雨板 & $3^{21 / 2}$ & 21 \\
\hline $\begin{array}{l}4 / 8 \\
41 / 2\end{array}$ & 22 & $13 / 4$ & 28 & $\begin{array}{cc}m m & m m \\
m 0 \times & 75\end{array}$ & & 造船木 & 利料 & $\begin{array}{r}\mathbf{5} / \mathbf{5}^{\prime \prime} \\
\mathbf{m}^{2}\end{array}$ & $\begin{array}{l}15 \\
16\end{array}$ & $31 / 2$ & 23 \\
\hline $4 \frac{3}{4}$ & 14 & 2 & 17 & $\mid \begin{array}{l}90 \times 75 \\
110 \times 75\end{array}$ & 1 & $6^{\prime \prime} \times 6^{\prime \prime}$ & 34 & 䲞 & 31 & $\begin{array}{l}4 \\
41 / 2\end{array}$ & $\begin{array}{l}28 \\
64\end{array}$ \\
\hline $\begin{array}{l}5 \\
5\end{array}$ & $\begin{array}{l}20 \\
18\end{array}$ & $\begin{array}{l}21 / 4 \\
2^{1 / 2}\end{array}$ & $\begin{array}{r}5 \\
39\end{array}$ & $130 \times 75$ & 2 & 計 & 34 & 鐡力 & 板 & 5 & $\begin{array}{r}2 \\
2\end{array}$ \\
\hline $5 \pi / 2$ & 34 & $\begin{array}{l}3 \\
3^{3} / 2 / 2\end{array}$ & $\begin{array}{l}2 \\
1\end{array}$ & $150 \times 90$ & 17 & $\begin{array}{l}\text { 詰 } \\
\text { インンク }\end{array}$ & $\begin{array}{l}36 \\
-1\end{array}$ & $100 \mathrm{lbs}$ & 132 & $5^{5 / 2}$ & 7 \\
\hline $61 / 4$ & 21 & $3 \%$ & 1 & $\mid \begin{array}{l}160 \times 90 \\
165 \times 75\end{array}$ & $\begin{array}{l}2 \\
8\end{array}$ & at 1 & 956 & $\left|\begin{array}{c}170 \\
40 \text { sheets }\end{array}\right|$ & $\begin{array}{r}304 \\
2\end{array}$ & $6 \pi / 2$ & 9 \\
\hline $6^{1 / 2}$ & 17 & 33/8 & 2 & {$\left[\begin{array}{l}100 \times 10 \\
180 \times 90\end{array}\right.$} & 2 & 型售合针 & 2,472 & 50 & 7 & $6 \%$ & 62 \\
\hline 7 & $\begin{array}{l}23 \\
20\end{array}$ & 4 & 3 & $\begin{array}{l}200 \times 75 \\
230 \times 90 \times 90\end{array}$ & $\begin{array}{l}23 \\
25\end{array}$ & 候金会竐 & 3.576 & $6^{\prime} \mathrm{J}$ & 16 & 8 & 14 \\
\hline & $\begin{array}{r}52 \\
9\end{array}$ & $\begin{array}{l}5 \\
6\end{array}$ & $\begin{array}{l}1 \\
1\end{array}$ & $230 \times 90$ & 65 & 板 & の 部 & 80 & 3 & $10^{85 / 8}$ & $\begin{array}{r}823 \\
15\end{array}$ \\
\hline & 4 & $7 \mathrm{~mm}$ & ه & $\begin{array}{l}250 \times 90 \\
300 \times 90\end{array}$ & $\begin{array}{l}10 \\
16\end{array}$ & 雟板 $(07$ & $m m$ 超) & 100 & 19 & 12 & $\mathbf{3}$ \\
\hline $9 / 2$ & $1 \overline{2}$ & 13 & 2 & 斻 & 211 & 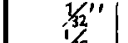 & 5 & Mixed & $\mathbf{3 4}$ & $32 \mathrm{~mm}$ & 13 \\
\hline 10 & 20 & 18 & 1 & 解 & 242 & 36 & $\begin{array}{r}168 \\
78\end{array}$ & il size & 1,835 & 57 & 8 \\
\hline $6 \mathrm{~mm}$ & 1 & 20 & 7 & 球山 & & & $\begin{array}{l}173 \\
198\end{array}$ & of & $\begin{array}{l}1,398 \\
3,754\end{array}$ & $\begin{array}{c}73 \\
\text { Pipetteting }\end{array}$ & $\begin{array}{l}49 \\
38\end{array}$ \\
\hline 8 & 1 & $\begin{array}{l}22 \\
26\end{array}$ & 2 & （连 & & $3 / 4$ & 32 & 板合計 & 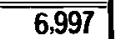 & Pipsjoint & 8 \\
\hline 12 & 3 & 30 & ?7? & $6^{\prime \prime} \times 3^{\prime \prime} \mid$ & $\begin{array}{r}5 \\
16\end{array}$ & 18 & $\begin{array}{r}10 \\
3\end{array}$ & 10 & 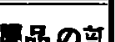 & 計 & 1,650 \\
\hline $\begin{array}{l}13 \\
28\end{array}$ & $\begin{array}{l}2 \\
2\end{array}$ & 竐 & 272 & $7 \times 3 \frac{1}{2}$ & 4 & $5 / 8$ & 13 & 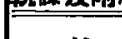 & & 造船才 & 材料 \\
\hline th & 691 & 其他 & & 8 & 43 & inl & 236 & & & $55 / 2 "$ & 2 \\
\hline 迩船 & & 竐 & 1 & $9 \times 3^{3 / 2}$ & 91 & $13^{2} / 2$ & $\begin{array}{l}5 \\
2\end{array}$ & $\begin{array}{c}9 \mathrm{lbs} \\
\text { Elerator 角 }\end{array}$ & $\begin{array}{l}29 \\
13\end{array}$ & 63 & 7 \\
\hline $2^{7 / 32}$ & 1 & 合 $\begin{array}{c} \\
\end{array}$ & 13 & $\pm / 2$ & 77 & $\begin{array}{l}14 \\
15\end{array}$ & $\begin{array}{r}10 \\
2\end{array}$ & 尌 & 42 & 計 & 9 \\
\hline 的 & 692 & 捷理合鲇 & 1,104 & $12 \times 31 / 2$ & 42 & 16 & $6 \overline{1}$ & 证特合計 & 42 & 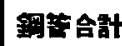 & $-1,659$ \\
\hline
\end{tabular}


昭和 5 年 10 月中當所品種寸法別生座高

（其二）（單位䣩）

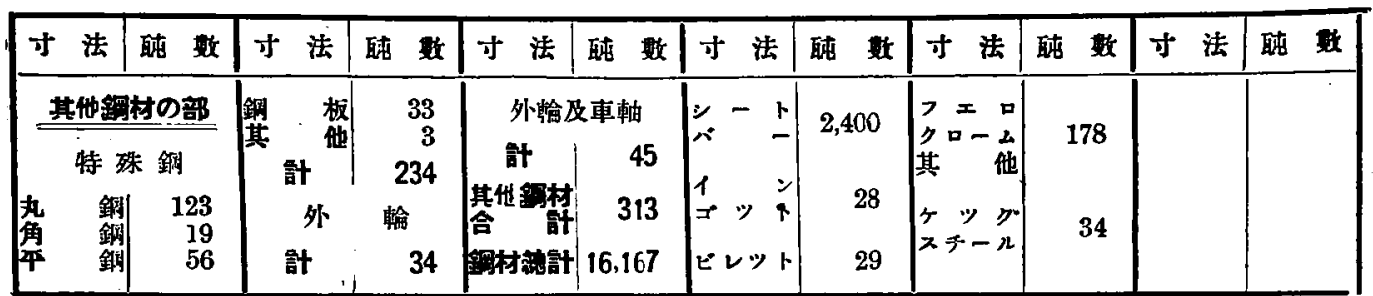

昭和 5 年 10.11 月渡先物契約數量表

(單位䣩)

\begin{tabular}{|c|c|c|}
\hline & & \\
\hline $6 \mathrm{~mm}$ & 二 & \\
\hline $\begin{array}{l}8 \\
9\end{array}$ & $\overline{3.290}$ & \\
\hline & 二 & \\
\hline & 55 & \\
\hline $\begin{array}{l}55 \\
60\end{array}$ & $\begin{array}{r}5 \\
15\end{array}$ & \\
\hline 65 & 10 & \\
\hline & & \\
\hline 80 & 10 & \\
\hline 90 & 25 & \\
\hline & 10 & \\
\hline 100 & 20 & \\
\hline 合計 & 3,450 & \\
\hline \multicolumn{3}{|c|}{ 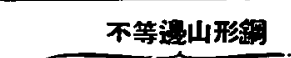 } \\
\hline \multirow{3}{*}{$\begin{array}{c}21 / 2 \times 2^{\prime \prime} \\
5 \times 4 \\
6 \times 31 / 2 \\
6 \times 4 \\
m i n m\end{array}$} & $\overline{-}$ & \\
\hline & 115 & \\
\hline & - & \\
\hline $\begin{array}{l}75 \times 50 \\
75 \times 65\end{array}$ & $\begin{array}{l}30 \\
10\end{array}$ & \\
\hline $\begin{array}{r}75 \times 60 \\
90 \times 75 \\
\end{array}$ & 10 & \\
\hline $\begin{array}{l}100 \times 76 \\
125 \times 75\end{array}$ & 55 & \\
\hline $125 \times 90$ & 20 & \\
\hline $150 \times 90$ & 169 & \\
\hline $\begin{array}{c}150 \times 100 \\
65 \times 50\end{array}$ & $\begin{array}{r}239 \\
10\end{array}$ & \\
\hline $75 \times 40$ & 36 & \\
\hline $100 \times 5$ & 10 & \\
\hline
\end{tabular}

\section{才法角能数 累棓}

$\begin{array}{lll}1 \% m m & 30 & 107 \\ 16 & 40 & 174\end{array}$

19

22

28

$\because 2$

98

218

44
50

50

65
75

60
100

100

129

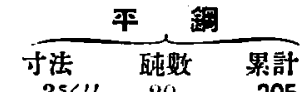

$\begin{array}{rrr}35 \% " & 30 & 395 \\ 19 & 115 & 1,062\end{array}$

22

25
32

32

38

$45-508$

$44 \quad-\quad 250$

511
55

55
65

$\begin{array}{rrr}10 & 88 & 75 \\ 10 & 217 & 90\end{array}$

$\begin{array}{rrr}10 & 217 & 90 \\ 10 & 93 & 100\end{array}$

合魬

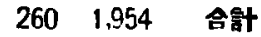

合計

工形铜

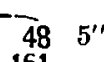

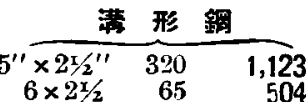
$\begin{array}{lrr}6 \times 2 \times 1 / 2 & 65 & 504 \\ 6 \times 3 & 175 & 1013\end{array}$ $\begin{array}{lll}7 \times 3 & 40 & 334\end{array}$ $7 \times 3 \frac{1}{2} \quad 20 \quad 401$

$1658 \times 21 / 2 \quad-\quad 65$

$1708 \times 3, \quad 5$ $8 \times 31_{2} \quad 27 \quad 293$

inm $\mathrm{mm}$

$18475 \times 40$

194

$259100 \times 50$

924

$230 \times 90$

$250 \times 90$

$300 \times 90$
$380 \times 100$

$$
-
$$

105
6 " $\times 3$ "

$\begin{array}{lll}14 \times 6 & - & 40 \\ 16 \times 6 & 85\end{array}$

$16 \times 6=$

$18 \times 7$

$20 \times 7 \frac{1}{2} \quad 100$

$24 \times 71=44$

$m m m$

$100 \times 75$

$125 \times 75$

45
60

$150 \times 125$

$200 \times 100$

$200 \times 150$

$230 \times 100$

$250 \times 125$

$300 \times 150$

$350 \times 150$

$400 \times 150$

$15) \times 75$

41
115
5
25
135

324
$4 !$
171
118

$+$

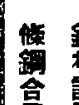

定 期 先 物 合㝄 累

8,867 剔下㬄 8.867

1,493

10,360

表發2 1,493

K表 10,360

$48,485 \quad 69,848$
等过山山形等

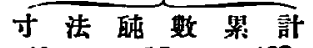

$40 \mathrm{~mm} \quad 15 \quad 463$

$45 \quad-\quad 177$

$50 \quad 666 \quad 1,178$

$\begin{array}{lll}65 & 20 & 270\end{array}$

$\begin{array}{lll}75 & 34 & 279\end{array}$

90

100

5

13) 523

$200 \quad-\quad 185$

$20 \mathrm{~mm} \quad 10 \quad 10$

$\begin{array}{lll}25 & 15 & 15 \\ 30 & 25 & 25\end{array}$

合計 7042,665 合計 962

储考 累計は本件 4 月渡上りとす

6,386 合計 $1,2984,816$ 合計 1,493

12,299 
昭和 5 年 11,12 月渡定期先物契約數表

（單位碻）

\begin{tabular}{|c|c|c|c|c|c|c|c|c|c|c|c|}
\hline \multicolumn{3}{|c|}{ 丸，銅 } & \multicolumn{3}{|c|}{ 角，铜 } & \multicolumn{3}{|c|}{ 平，銅 } & \multicolumn{3}{|c|}{ 等息山形铻 } \\
\hline 寸法 & 神数 & 累計 & 可法 & 䣩数 & 累計 & 寸法 & $\underbrace{}_{\text {䣩數 }}$ & 累竐 & 才法 & 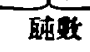 & 累棓 \\
\hline $\begin{array}{c}6 \mathrm{~mm} \\
\mathbf{8} \\
\mathbf{9} \\
\cdot 11 \\
12\end{array}$ & $\begin{array}{l}\bar{z} \\
\overline{3,108} \\
\overline{ }\end{array}$ & $\begin{array}{r}513 \\
310 \\
26,457 \\
10 \\
687\end{array}$ & $\begin{array}{l}12 \mathrm{~mm} \\
16 \\
19 \\
22 \\
25\end{array}$ & $\frac{-}{3}$ & $\begin{array}{r}107 \\
.174 \\
3,161 \\
54 \\
139\end{array}$ & $\begin{array}{c}35 \% \\
19 \mathrm{~m} \\
22 \\
25 \\
32\end{array}$ & $\begin{array}{r}\overline{5} \\
-5 \\
-\end{array}$ & $\begin{array}{r}395 \\
1,067 \\
897 \\
956 \\
809\end{array}$ & $\begin{array}{l}20 \mathrm{~mm} \\
25 \\
30 \\
40 \\
45\end{array}$ & $\begin{array}{r}\overline{20} \\
5 \\
5 \\
-\end{array}$ & $\begin{array}{r}10 \\
35 \\
30 \\
468 \\
177\end{array}$ \\
\hline $\begin{array}{l}50 \\
55 \\
60 \\
65 \\
70\end{array}$ & $\begin{array}{l}= \\
=\end{array}$ & $\begin{array}{r}336 \\
259 \\
98 \\
218 \\
93\end{array}$ & $\begin{array}{l}28 \\
32 \\
38 \\
44 \\
50\end{array}$ & $\begin{array}{l}= \\
\bar{z}\end{array}$ & $\begin{array}{r}43 \\
219 \\
345 \\
173 \\
129\end{array}$ & $\begin{array}{l}38 \\
44 \\
50 \\
55 \\
65\end{array}$ & $\begin{array}{l}\bar{z} \\
\overline{19}\end{array}$ & $\begin{array}{r}508 \\
250 \\
831 \\
15 \\
788\end{array}$ & $\begin{array}{r}50 \\
65 \\
75 \\
90 \\
100\end{array}$ & $\begin{array}{r}553 \\
130 \\
55 \\
35\end{array}$ & $\begin{array}{r}1,731 \\
270 \\
409 \\
80 \\
121\end{array}$ \\
\hline $\begin{array}{r}75 \\
80 \\
90 \\
95 \\
100\end{array}$ & $\begin{array}{l}= \\
=\end{array}$ & $\begin{array}{r}162 \\
71 \\
160 \\
53 \\
106\end{array}$ & $\begin{array}{r}65 \\
75 \\
90 \\
100\end{array}$ & $=$ & $\begin{array}{r}88 \\
217 \\
93 \\
17\end{array}$ & $\begin{array}{r}75 \\
90 \\
100\end{array}$ & $\begin{array}{l}- \\
--\end{array}$ & $\begin{array}{l}843 \\
291 \\
217\end{array}$ & $\begin{array}{l}130 \\
150 \\
200\end{array}$ & $\begin{array}{r}353 \\
285 \\
-\end{array}$ & $\begin{array}{r}2,255 \\
3,135 \\
185\end{array}$ \\
\hline 㝇 & 3,108 & 29,533 & 合鯜 & 5 & 1,959 & 合計 & 29 & 7.867 & 合㢵 & 1,441 & 8,906 \\
\hline
\end{tabular}

\begin{tabular}{|c|c|c|}
\hline \multicolumn{3}{|l|}{ 不 } \\
\hline $\begin{array}{c}2{ }^{1 / 21} \times 2^{\prime \prime} \\
5 \times 4 \\
6 \times 3^{1} / 2 \\
6 \times 4\end{array}$ & $\frac{\overline{4}}{-}$ & $\begin{array}{l}48 \\
206 \\
105 \\
276\end{array}$ \\
\hline $\begin{array}{c}m m m m \\
65 \times 50\end{array}$ & - & \\
\hline $75 \times 40$ & - & 36 \\
\hline $75 \times 50$ & - & 165 \\
\hline $75 \times 65$ & - & 170 \\
\hline $\begin{array}{r}-9 J \times 75 \\
100 \times 50\end{array}$ & - & $\begin{array}{l}61 \\
10\end{array}$ \\
\hline $100 \times 75$ & - & 52 \\
\hline $125 \times 75$ & 10 & \\
\hline $\begin{array}{l}125 \times 90 \\
150 \times 90\end{array}$ & 13 & 394 \\
\hline $150 \times 100$ & 180 & 1,107 \\
\hline
\end{tabular}

\begin{tabular}{|c|c|c|}
\hline \multicolumn{3}{|c|}{ 清形铜 } \\
\hline $\begin{array}{c}5^{\prime \prime} \times 2 \mathrm{x} / \mathrm{I}^{\prime \prime} \\
6 \times 2 \mathrm{x} / 2 \\
6 \times 3 \\
7 \times 3 \\
7 \times 3 \mathrm{x} / 2\end{array}$ & $\begin{array}{r}281 \\
12 ! \\
3: 35 \\
63 \\
35\end{array}$ & $\begin{array}{r}1,404 \\
624 \\
1,348 \\
397 \\
436\end{array}$ \\
\hline $\begin{array}{l}8 \times 25 / 2 \\
8 \times 3 \\
8 \times 31 / 2\end{array}$ & $\frac{-}{26}$ & \\
\hline $\begin{array}{r}m m m m \\
75 \times 40 \\
100 \times 50\end{array}$ & - & \\
\hline $\begin{array}{l}230 \times 8 \mathrm{~J} \\
230 \times 9 \mathrm{~J} \\
250 \times 90 \\
300 \times 90 \\
380 \times 100\end{array}$ & $\begin{array}{l}30 \\
63 \\
81 \\
84 \\
75\end{array}$ & \\
\hline
\end{tabular}

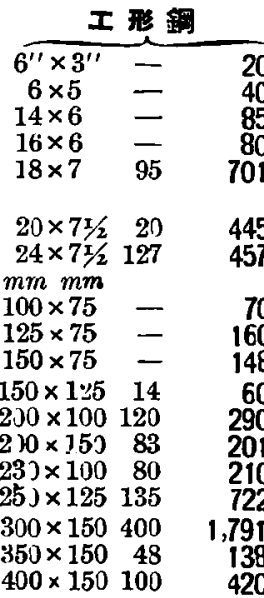

\begin{tabular}{|c|c|c|}
\hline & 鋼 & 梪 \\
\hline $\begin{array}{l}1 \cdot 6 \mathrm{~mm} \\
2 \cdot 3 \\
3 \cdot 2 \\
4 \cdot 5 \\
6\end{array}$ & $\begin{array}{r}614 \\
164 \\
806 \\
208 \\
15\end{array}$ & $\begin{array}{r}5,858 \\
1,358 \\
5,561 \\
956 \\
265\end{array}$ \\
\hline$y$ & - & $\begin{array}{l}66 \\
56\end{array}$ \\
\hline
\end{tabular}

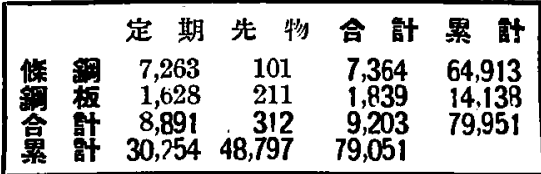

$\begin{array}{lllllllllllll}\text { 合 领 } 370 & 3,035 & \text { 合 計 } 1,189 & 7,575 & \text { 合 } & \text { it } & 1,222 & 6,038 & \text { 合 } & \text { th } & 1,839 & 14,138\end{array}$

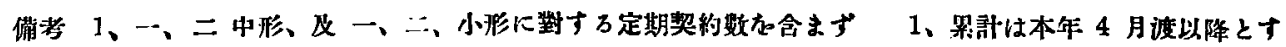




\begin{tabular}{|c|c|c|c|c|c|c|c|c|c|}
\hline \multirow{2}{*}{$\begin{array}{l}\text { 廆分 } \\
\text { 寸啮 }\end{array}$} & \multicolumn{4}{|c|}{ 民間向晋涌鉱 } & \multicolumn{4}{|c|}{ 格規品及特䛈銅 } & \\
\hline & $\begin{array}{l}\text { 阪市㙂 } \\
\text { 揚 }\end{array}$ & $\begin{array}{l}\text { 京浙 } \\
\text { 揬 }\end{array}$ & 其 & 郭 & $\begin{array}{l}\text { 阪神 } \\
\text { 荡 }\end{array}$ & $\begin{array}{l}\text { 京㴼 } \\
\text { 揚 }\end{array}$ & 其 & 計 & 合計 \\
\hline $\begin{array}{l}5 \mathrm{~mm} \\
6 \\
7 \\
7 \cdot 5 \\
8\end{array}$ & $\begin{array}{l}= \\
\overline{-} \\
-\end{array}$ & $\begin{array}{l}\overline{5} \\
- \\
-5\end{array}$ & $\begin{array}{r}\overline{5} \\
31 \\
-\end{array}$ & $\begin{array}{l}\overline{10} \\
\frac{31}{5}\end{array}$ & $\begin{array}{l}\bar{z} \\
\overline{-}\end{array}$ & $\begin{array}{l}E \\
-\end{array}$ & $\begin{array}{r}1 \\
4 \\
3 \\
-\end{array}$ & $\begin{array}{r}1 \\
4 \\
3 \\
-\end{array}$ & $\begin{array}{r}1 \\
14 \\
31 \\
3 \\
5\end{array}$ \\
\hline $\begin{array}{l}9 \\
10.5 \\
11 \\
12 \\
15\end{array}$ & $\begin{array}{c}\frac{610}{6)} \\
160 \\
-\end{array}$ & $\begin{array}{r}1,326 \\
115 \\
120 \\
-\end{array}$ & $\begin{array}{l}173 \\
= \\
-\end{array}$ & $\begin{array}{r}3,139 \\
175 \\
280 \\
-\end{array}$ & $\begin{array}{l}\bar{z} \\
\overline{-}\end{array}$ & $\begin{array}{l}- \\
\overline{-} \\
-\end{array}$ & $\begin{array}{r}1 \\
\frac{1}{16} \\
5\end{array}$ & $\frac{13}{1}$ & $\begin{array}{r}3140 \\
1 \\
175 \\
296 \\
5\end{array}$ \\
\hline $\begin{array}{l}16 \\
18 \\
19 \\
21 \\
28\end{array}$ & $\begin{array}{l}I \\
\bar{z}\end{array}$ & $\begin{array}{l}- \\
\overline{-}\end{array}$ & - & $\begin{array}{l}\bar{z} \\
\bar{z}\end{array}$ & $\begin{array}{l}\bar{z} \\
\overline{-}\end{array}$ & $\begin{array}{l}\text { 二 } \\
\text { - }\end{array}$ & $\begin{array}{r}6 \\
3 \\
29 \\
1 \\
21\end{array}$ & $\begin{array}{r}6 \\
3 \\
29 \\
1 \\
21\end{array}$ & $\begin{array}{r}6 \\
3 \\
29 \\
1 \\
21\end{array}$ \\
\hline $\begin{array}{l}24 \\
25 \\
28 \\
32 \\
38\end{array}$ & $\begin{array}{l}- \\
\overline{-} \\
-\end{array}$ & $\begin{array}{l}E \\
\bar{z}\end{array}$ & $\begin{array}{l}z \\
z\end{array}$ & $\begin{array}{l}\bar{z} \\
\overline{-} \\
-\end{array}$ & $\begin{array}{l}- \\
\overline{-}\end{array}$ & $\begin{array}{l}\bar{z} \\
\overline{-}\end{array}$ & $\begin{array}{r}2 \\
1 \\
3 \\
3 \\
11\end{array}$ & $\begin{array}{r}2 \\
1 \\
3 \\
3 \\
11\end{array}$ & $\begin{array}{r}3 \\
3 \\
11\end{array}$ \\
\hline $\begin{array}{l}50 \\
55 \\
60\end{array}$ & $\begin{array}{l}- \\
10 \\
21 \\
33\end{array}$ & $\begin{array}{l}- \\
z \\
-\end{array}$ & $\begin{array}{l}\bar{z} \\
\bar{z}\end{array}$ & $\begin{array}{l}- \\
10 \\
21 \\
33\end{array}$ & $\begin{array}{l}\bar{z} \\
= \\
=\end{array}$ & $\begin{array}{l}\bar{z} \\
\bar{z}\end{array}$ & $\begin{array}{r}8 \\
3 \\
11 \\
8 \\
-\end{array}$ & $\begin{array}{r}8 \\
3 \\
11 \\
8 \\
-\end{array}$ & $\begin{array}{r}8 \\
3 \\
21 \\
29 \\
33\end{array}$ \\
\hline $\begin{array}{l}65 \\
70 \\
75 \\
81 \\
90\end{array}$ & $\begin{array}{c}29 \\
23 \\
1 \\
10\end{array}$ & $\begin{array}{l}\bar{z} \\
\overline{117}\end{array}$ & $\begin{array}{l}\bar{z} \\
\overline{2}\end{array}$ & $\begin{array}{r}20 \\
23 \\
1 \\
129\end{array}$ & $\begin{array}{l}\bar{z} \\
\overline{-}\end{array}$ & $\begin{array}{l}\overline{-} \\
\overline{10}\end{array}$ & $\begin{array}{r}13 \\
2 \\
7 \\
8 \\
18\end{array}$ & $\begin{array}{r}13 \\
2 \\
7 \\
8 \\
28\end{array}$ & $\begin{array}{r}33 \\
2 \\
30 \\
9 \\
157\end{array}$ \\
\hline $\begin{array}{r}95 \\
100 \\
105 \\
110 \\
112\end{array}$ & $\begin{array}{l}I \\
\overline{-} \\
=\end{array}$ & $\begin{array}{l}- \\
\overline{-} \\
-\end{array}$ & $\begin{array}{l}- \\
\overline{-} \\
-\end{array}$ & $\begin{array}{l}= \\
= \\
=\end{array}$ & $\begin{array}{l}\bar{z} \\
\overline{-}\end{array}$ & $\begin{array}{l}= \\
=\end{array}$ & $\begin{array}{l}1 \\
1 \\
1 \\
4 \\
-\end{array}$ & $\begin{array}{r}1 \\
1 \\
1 \\
4 \\
-\end{array}$ & $\begin{array}{r}1 \\
1 \\
1 \\
4 \\
-\end{array}$ \\
\hline $\begin{array}{l}115 \\
124 \\
130 \\
140 \\
15 .\end{array}$ & $\begin{array}{l}\overline{-} \\
\overline{33} \\
\overline{16}\end{array}$ & $\begin{array}{l}- \\
\overline{1}\end{array}$ & $\begin{array}{l}\overline{-} \\
\bar{z}\end{array}$ & $\frac{\overline{-}}{\frac{39}{16}}$ & $\begin{array}{l}\overline{-} \\
\overline{-}\end{array}$ & $\begin{array}{l}\bar{z} \\
\overline{-} \\
-\end{array}$ & $\begin{array}{l}5 \\
\ddot{3} \\
1 \\
2 \\
-\end{array}$ & $\begin{array}{l}5 \\
3 \\
1 \\
2 \\
\end{array}$ & $\begin{array}{r}5 \\
3 \\
40 \\
2 \\
16\end{array}$ \\
\hline $\begin{array}{l}180 \\
190 \\
200\end{array}$ & $\begin{array}{r}12 \\
3 \\
34 \\
35 \\
19\end{array}$ & $\begin{array}{l}\overline{-} \\
\overline{6}\end{array}$ & $\begin{array}{l}\bar{Z} \\
\bar{Z}\end{array}$ & $\begin{array}{r}12 \\
3 \\
34 \\
44 \\
19\end{array}$ & $\begin{array}{l}\overline{-} \\
\overline{-}\end{array}$ & $\begin{array}{l}\bar{z} \\
\overline{-}\end{array}$ & $\begin{array}{l}\bar{z} \\
z \\
-\end{array}$ & $\begin{array}{l}\bar{z} \\
\frac{2}{-}\end{array}$ & $\begin{array}{r}12 \\
3 \\
36 \\
44 \\
19\end{array}$ \\
\hline
\end{tabular}

九䤡解 2,1331,6842114,044 - 102292194,263

區分 民間向曾通銅 规格品及特殊銅

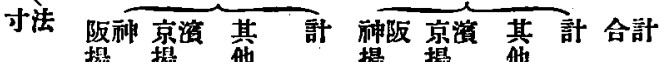

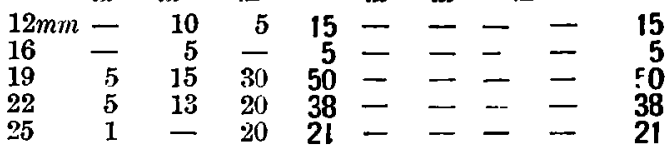

$$
\begin{aligned}
& 28-3=3--\div=-3 \\
& 38 \text { i5 } \overline{25}=40=\overline{-}={ }_{40} \\
& \begin{array}{rrr}
44 & 5 \\
50 & -\quad 5 & -5
\end{array}
\end{aligned}
$$

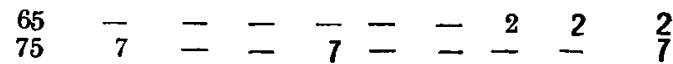

角銅䚾 $48 \quad 79 \quad 75202 \quad-\quad 1 \quad 5 \quad 6 \quad 208$ ד下

$$
\begin{aligned}
& \begin{array}{lrrrr}
19 \mathrm{~mm} 28 & 13 & 20 & 56 & \\
22 & 9 & 5 & 5 & 14 \\
25 & 15 & 3 & 4 & 22
\end{array} \\
& 32 \quad 10 \quad 3 \quad 5 \quad 18=--5 \\
& \begin{array}{llllllllll}
38 & 125 & 125 & 1 & 251 & - & - & 5 & 5 & 256
\end{array} \\
& \begin{array}{rrrrrrrrrr}
44 & 45 & 43 & 1 & 89 & - & - & 89
\end{array} \\
& 50 \text { 12; 19) } 14324=-2 \quad 2 \quad 326 \\
& \begin{array}{lrrrr}
65 & 75 & 315 & 14 & 404 \\
75 & - & 14 & - & 14
\end{array}=-\begin{array}{lll}
1 & 1 & 405 \\
14
\end{array}
\end{aligned}
$$

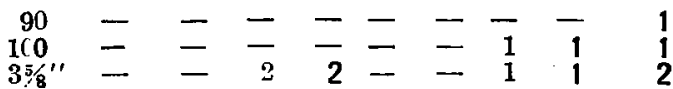

昭和 5 年 10 月中當所些品揚地別發送高

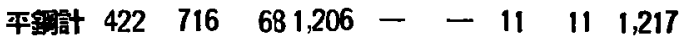
合 st 2,608 2,490 354,5,452-11225 2365,688

揚 地 别

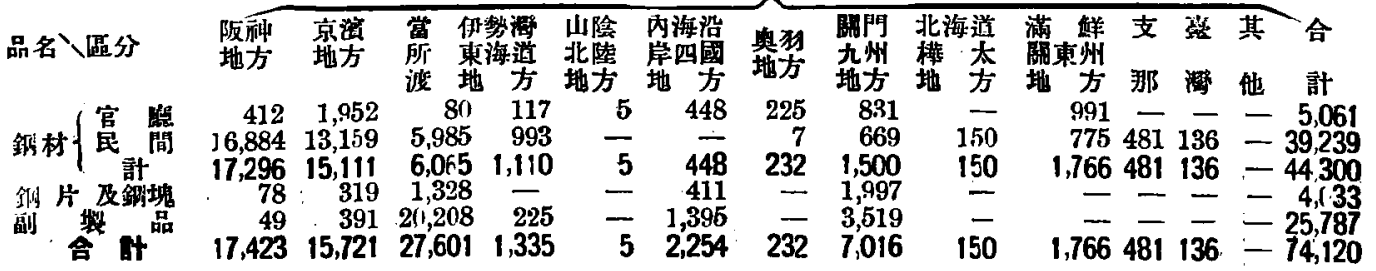


昭和 5 年10月中當所品種寸法別生産高

（單位䣩）

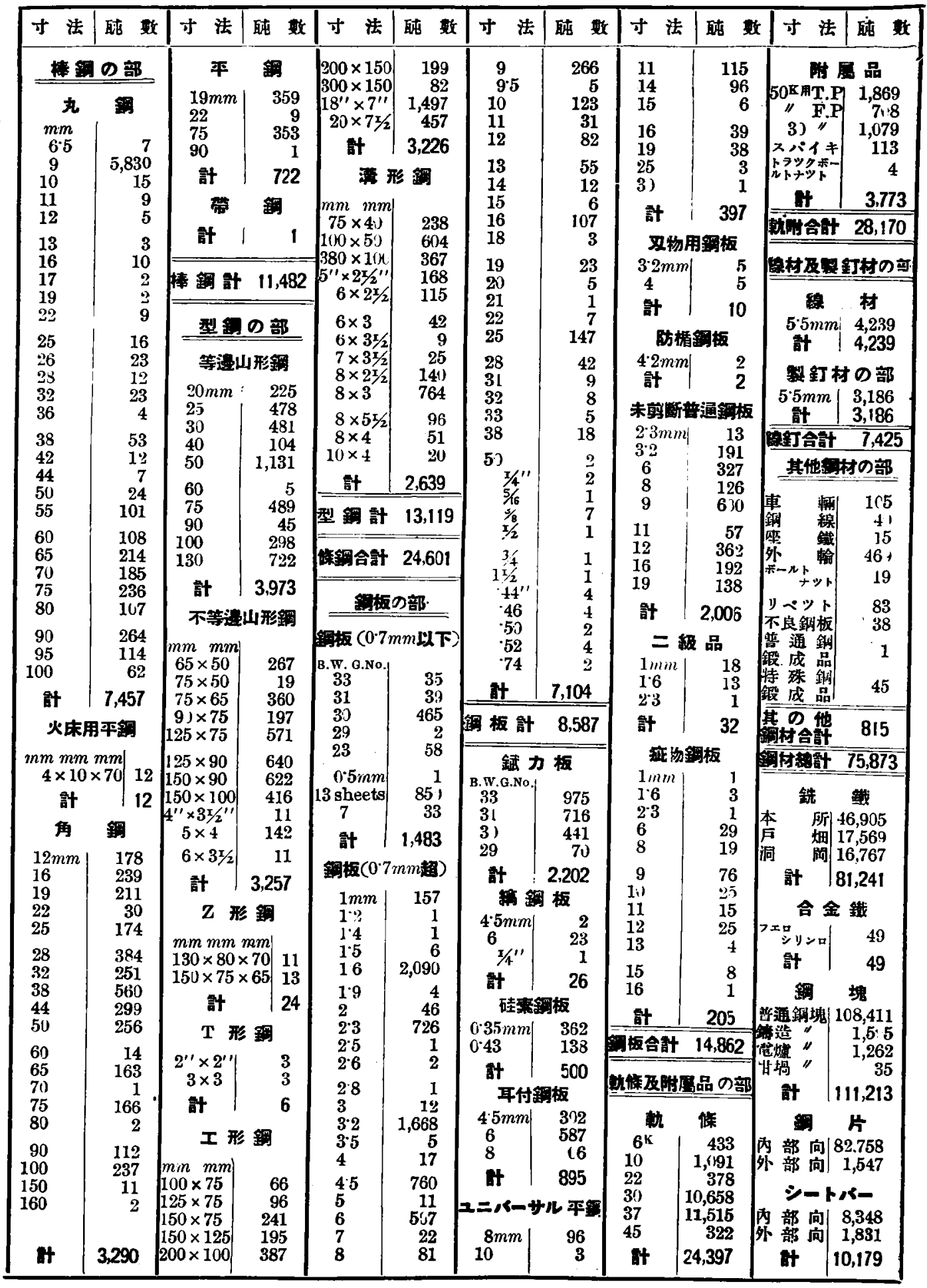


昭和 5 年 9 月民間棒網生虐高表

（單位䣩）

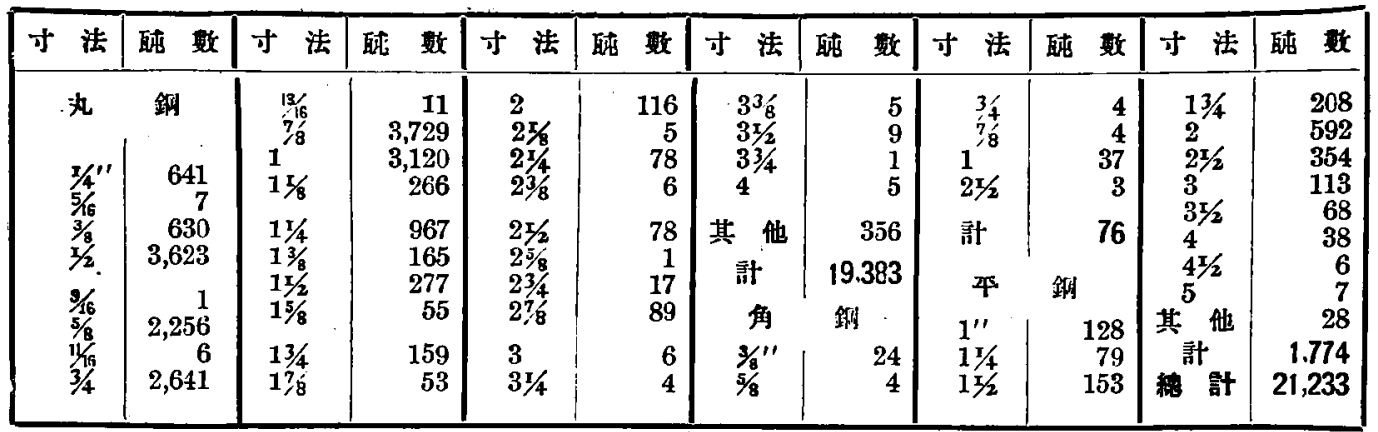

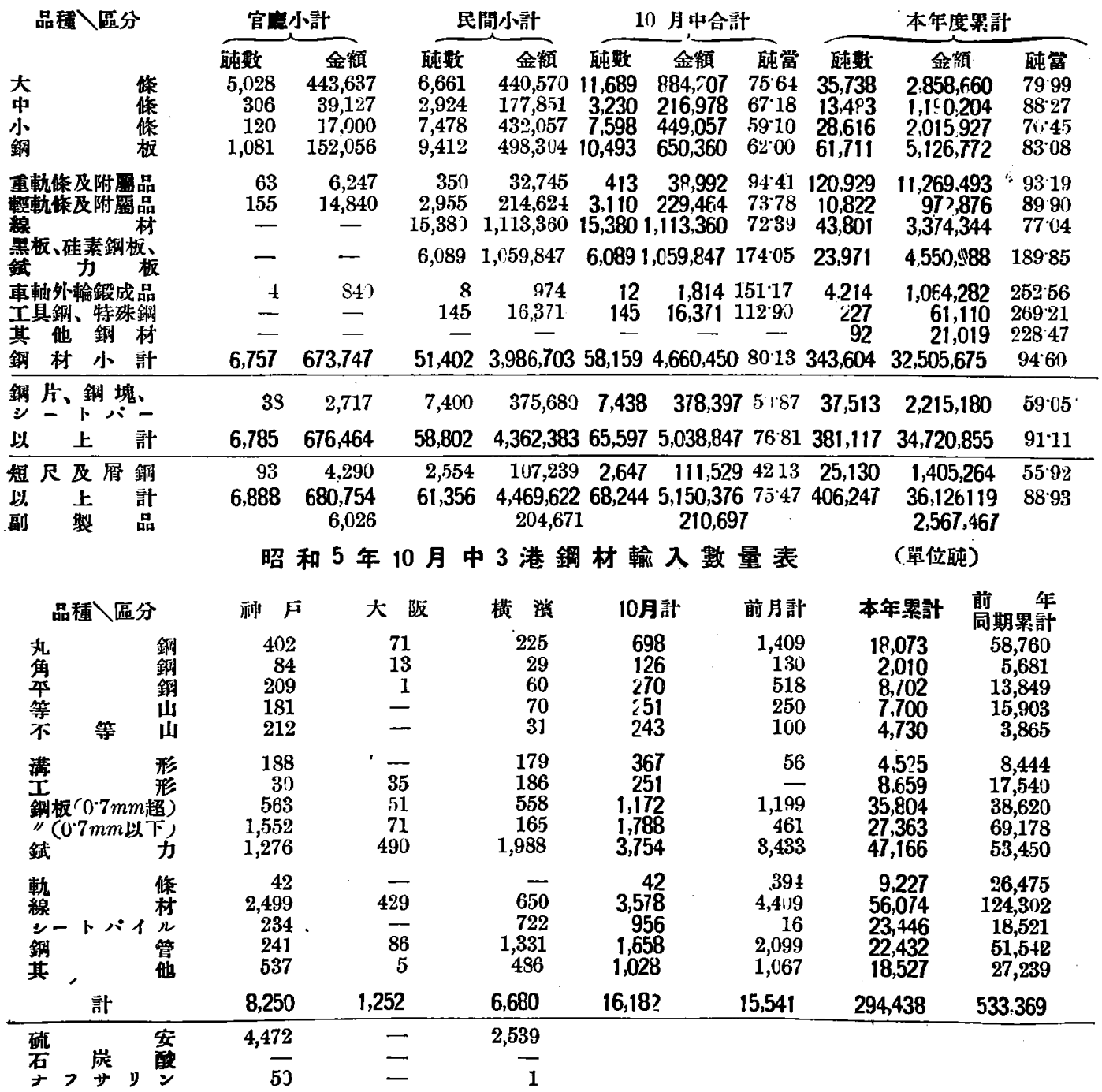

